\title{
Management of chronic hepatitis B: Consensus guidelines
}

\author{
Morris Sherman MD PhD ${ }^{1}$, Stephen Shafran $M D^{2}$, Kelly Burak $M D^{3}$, Karen Doucette $M D^{2}$, Winnie Wong $M D^{2}$, \\ Nigel Girgrah $M D^{1}$, Eric Yoshida $M D^{4}$, Eberhard Renner $M D^{5}$, Philip Wong $M D^{6}$, Marc Deschênes $M D^{6}$
}

M Sherman, S Shafran, K Burak, et al. Management of chronic hepatitis B: Consensus guidelines. Can J Gastroenterol 2007;21(Suppl C):5C-24C.

The present document presents the proceedings of the consensus development conference on the management of viral hepatitis held in January 2007 under the auspices of the Canadian Association for the Study of the Liver and the Association of Medical Microbiology and Infectious Disease Canada. Several new agents have become available since the last such document was published in 2004, and new information has become available to help assess risk of adverse outcomes and who should be treated. In addition, the participants at the meeting identified a number of structural barriers that exist uniquely in Canada and that prevent physicians from properly managing their patients. The conference discussed the selection of patients for treatment and the drugs that can be used to treat these patients, as well as the treatment of hepatitis B in special populations. The present document should be read in conjunction with the companion document on the management of chronic hepatitis $\mathrm{C}$.

\section{La prise en charge de l'hépatite $B$ chronique : Des lignes directrices consensuelles}

Key Words: Adefovir dipivoxil; Chronic hepatitis B; Entecavir; Hepatitis B vaccination; Lamivudine; Telbivudine; Tenofovir disiproxil

\begin{tabular}{|c|c|}
\hline $\begin{array}{l}\text { health and medical problem in Canada. There are an esti- } \\
\text { ated 500,000 to 600,000 people in Canada infected with } \\
\text { ther the hepatitis B virus (HBV) or the hepatitis C virus } \\
\mathrm{HCV} \text { ). Both viruses cause liver disease that is usually indo- } \\
\text { nt, and it takes many years to cause symptoms, as well as to } \\
\text { use the life-threatening conditions of cirrhosis, liver failure } \\
\text { d liver cancer. There are data suggesting that the incidence } \\
\text { these conditions is increasing in Canada (1). Furthermore, } \\
\text { le demographics (eg, age and country of origin) of the infected } \\
\text { opulation in Canada suggest that the incidence of these dire } \\
\text { nnsequences will continue to increase in frequency over the } \\
\text { ext } 20 \text { years or more unless effective treatment is widely } \\
\text { eployed (1). Effective treatment is now available for both } \\
\text { epatitis B and hepatitis C that should reduce the frequency of } \\
\text { lverse outcomes. New drugs have recently become available, }\end{array}$ & $\begin{array}{l}\text { tion of funding of laboratory tests and drug therapy, which } \\
\text { currently prevent the provision of optimal treatment to many } \\
\text { of those who need it. } \\
\text { For more than } 10 \text { years, the Canadian Association for the } \\
\text { Study of the Liver (CASL) has spearheaded the development } \\
\text { of guidelines to assist practitioners in the management of viral } \\
\text { hepatitis. More recently, the guidelines were developed in con- } \\
\text { junction with partner organizations, both medical and govern- } \\
\text { mental. Given the substantial changes that have occurred in } \\
\text { the management of these diseases over the past three to four } \\
\text { years, CASL, in conjunction with the Association of Medical } \\
\text { Microbiology and Infectious Disease Canada, organized another } \\
\text { consensus conference on the management of viral hepatitis. } \\
\text { The present report is the proceeds of that conference, held in } \\
\text { Toronto, Ontario, from January } 4 \text { to } 5,2007 \text {. } \\
\text { Funding }\end{array}$ \\
\hline
\end{tabular}

${ }^{1}$ Department of Medicine, University of Toronto, Toronto, Ontario; ${ }^{2}$ Department of Medicine, University of Alberta, Edmonton, Alberta; ${ }^{3}$ Department of Medicine, University of Calgary, Calgary, Alberta; ${ }^{4}$ Department of Medicine, University of British Columbia, Vancouver, British Columbia;

${ }^{5}$ Department of Medicine, University of Manitoba, Winnipeg, Manitoba; ${ }^{6}$ Department of Medicine, McGill University, Montreal, Quebec

Correspondence: Dr Morris Sherman, Toronto General Hospital, Room NCSB 11C-1252, 585 University Avenue, Toronto, Ontario

M5G 2N2. Telephone 416-340-4756, fax 416-591-2107, e-mail morris.sherman@uhn.on.ca 


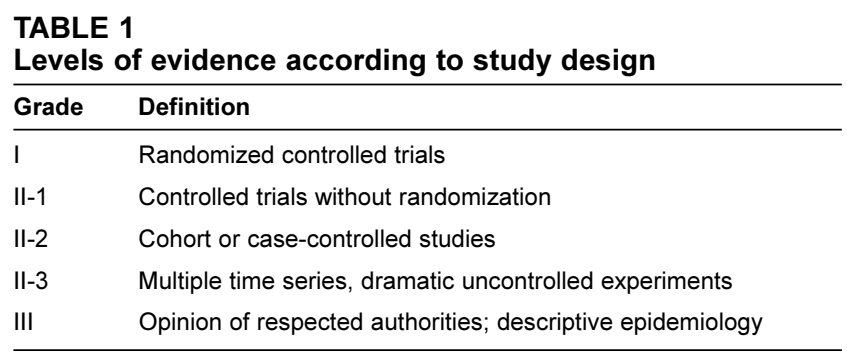

Data from reference 159

Squibb, Roche Canada, Gilead, Novartis and Valeant Canada. Additional funding was provided by the Hepatitis C Secretariat of the Ministry of Health and Long-Term Care of the Province of Ontario and the Hepatitis C Division of the Public Health Agency of Canada. Funding from the pharmaceutical industry is not the preferred method of funding consensus conferences, but in the absence of adequate governmental sources, the pharmaceutical industry is the only avenue to fund these important conferences. In other western countries, these consensus management conferences are fully supported by the national governments (eg, National Institutes of Health in the United States).

Recommendation 1: The Federal and/or Provincial Ministries of Health should agree to support periodic consensus development and treatment guidelines development conferences that focus on diseases of public health importance (III).

\section{Disclosures}

This will serve as a general disclosure for all speakers and the members of the writing committee. Many, but not all, of the speakers and writers have or have had relationships with the industry sponsors. These relationships include having received research grants, honoraria for speaking engagements or for work on advisory boards related to all of the products discussed in the present document. Some participants have received consulting fees from the Ontario Ministry of Health and LongTerm Care and Health Canada.

\section{Process}

An organizing committee was appointed by the two sponsoring organizations. This committee invited speakers considered experts to review the current literature on different topics. After the presentation questions were entertained from the audience, a writing committee, also selected by the organizing committee, synthesized the information from the presentations, and from other sources, and prepared a document that was circulated to the speakers for comment. The strength of the recommendations and the strength of the evidence supporting the recommendations are given (Table 1). The preparation of the present document was guided by the principle that the advice provided should represent best medical practice and is meant to indicate optimal therapy for patients. Considerations of cost were taken into account. It is clearly indicated where cost considerations dictated treatment that was less than optimal, and recommendations for optimal treatment are provided. For example, lamivudine remains a recommended therapy for hepatitis B. However, if cost were not a factor, lamivudine would no longer be recommended as firstline therapy for hepatitis B.

\section{STRUCTURAL BARRIERS TO EFFECTIVE MANAGEMENT OF VIRAL HEPATITIS}

Over the years, as the cost of treatment of viral hepatitis has increased, provincial drug formularies have put restrictions on the use of antiviral therapy. These vary from province to province, resulting in a lack of uniformity of access across the country. However, because knowledge has advanced, many of these restrictions are out of date and severely restrict the ability of physicians to provide optimal care to patients, particularly to those with less advanced disease. Provincial reimbursement formularies have not kept up to date with the changes in practice. Liver disease should be considered as a chronic disease with severe long-term outcomes that can be prevented by timely application of treatment. In this respect, it is no different than treating hypertension or hyperlipidemia. Funding for treatment of other chronic diseases is available long before the advent of severe complications. Likewise, funding for the management of viral hepatitis should be available before advanced disease is diagnosed. Other structural barriers include the slow approval process for medications (a problem not restricted to viral hepatitis) and the multiple layers of bureaucracy that approvals have to pass though, including licensing through Health Canada, the Patented Medicines Price Review Board, the Common Drug Review and, finally, provincial Drugs and Therapeutics Committees. There are many examples of access to effective therapies for viral hepatitis being delayed (sometimes for years) or denied through these processes.

Recommendation 2: Liver disease should be considered as a chronic disease with severe long-term outcomes that can be prevented by timely application of treatment (III).

Another structural barrier is that most virological blood tests are performed in public health laboratories that restrict the type and frequency of testing that they are prepared to do. As a result, useful, even vital, tests, such as hepatitis B resistance genotyping, are not widely available. Finally, effective management of viral hepatitis requires the services of many disciplines, including physicians, nurses, addiction medicine specialists and social workers. These services can only be effectively delivered in a clinic setting. There are very few governmentfunded clinics for the management of viral hepatitis.

Government funding agencies generally rely only on the highest levels of evidence from randomized controlled trials to fund specific drugs. Short-term, pharmaceutical companysponsored trials are not designed to evaluate long-term outcomes, such as survival. However, these end points are often required by reimbursement agencies (eg, Common Drug Review). In many cases, evidence of improved survival from randomized controlled trials is unlikely to ever be available. Lower levels of evidence are often not acceptable, no matter how convinced expert physicians may be. Sir Austin Bradford Hill, one of the fathers of the randomized controlled trial, had this to say: "All scientific work is incomplete - whether it be behavioural or experimental. All scientific work is liable to be upset by advancing knowledge. That does not confer upon us a freedom to ignore the knowledge we already have, or to postpone the action it appears to demand at a given time". This suggests that the absence of high levels of evidence is not a reason not to act on what appears to be appropriate given current knowledge. 
There was strongly expressed consensus at the meeting that the current limitations on drug use and laboratory testing were too restrictive and severely interfered with the delivery of optimal care, particularly to patients with hepatitis B and, to a lesser extent, hepatitis C. In the interests of best patient outcomes and in fairness to hepatitis patients compared with patients with other chronic diseases, limitations on drug use and viral testing must be made less restrictive and more responsive to patient needs.

Recommendation 3: Limitations on drug reimbursement and viral load testing must reflect current best practices as recommended by experts in the management of hepatitis B and hepatitis C (III).

\section{Nursing support in the management of chronic viral hepatitis} Specialist hepatitis nursing support is essential in the management of viral hepatitis. It is not an exaggeration to say that without nursing support, treatment of viral hepatitis, particularly hepatitis $\mathrm{C}$, is not possible. Very few physicians have the time needed to educate patients and monitor them during treatment. This task has been assumed by specialist hepatitis and hepatology nurses who are now the main providers of care for and education of patients about their disease and about the treatment. The nurses teach self-injection and monitor patients on therapy. However, they also do much more. They provide support to the patient that busy physicians cannot, and they are more accessible than physicians. It is fair to say that by assuming many of the patient care responsibilities, they support both the patient and the physician. Currently, most hepatitis nurses in Canada are funded by the pharmaceutical industry. This results in a conflict of interest on the part of the nurse because his or her income comes from the company that makes the drug used. That only a minority of nursing positions across the country are publicly funded is unacceptable to doctors and nurses, and should be unacceptable to government.

Recommendation 4: Publicly funded comprehensive hepatitis nursing programs should be instituted in all provinces as a matter of urgency (III).

\section{NORMAL ALANINE AMINOTRANSFERASE CONCENTRATION AND THE MANAGEMENT OF VIRAL HEPATITIS}

Traditionally, the blood test that has been used as a marker of liver injury and as the gatekeeper test for treatment of viral hepatitis was alanine aminotransferase (ALT). Previous guidelines from professional societies (including CASL) stressed that the ALT level should be elevated (to varying levels in different diseases) before treatment was undertaken (2-5). Recent data, however, have shed doubt on the use of ALT as a measure of liver disease severity, as a predictor of liver disease outcome and as a threshold for treatment consideration (6-11).

There is variation in the methods used in different laboratories to measure ALT, resulting in different normal ranges being reported. The majority of laboratories do not report differences for men and women, and give an upper limit of normal of $35 \mathrm{IU} / \mathrm{mL}$ to $40 \mathrm{IU} / \mathrm{mL}$. However, the normal range, established as 2 SDs from the mean, was derived many years ago from populations of subjects in which occult liver disease (eg, hepatitis C, nonalcoholic fatty liver disease and alcoholic liver disease) must have been present because none of these conditions could be diagnosed serologically. More recent data from large populations that excluded patients at risk for these conditions have suggested that the true upper limit of normal for ALT is $30 \mathrm{IU} / \mathrm{mL}$ for men and $19 \mathrm{IU} / \mathrm{mL}$ for women (assuming an assay with an upper limit of normal of $35 \mathrm{IU} / \mathrm{mL}$ to $40 \mathrm{IU} / \mathrm{mL})(6)$.

Studies in very large populations have shown that liverrelated and overall mortality in patients, and in so-called normal populations, started to rise when the ALT level exceeded 0.5 times the upper limit of the usual laboratory normal and increased with increasing ALT level. This has been shown in large, unselected populations (7) and in patients with chronic hepatitis $B(8)$. In addition, there are many studies $(9,10)$ in patients with hepatitis $B$ and hepatitis $C$ that show that a normal ALT level may be associated with significant liver injury, including cirrhosis. Furthermore, patients with hepatitis $\mathrm{C}$ and 'normal' baseline ALT levels who undergo anti-HCV therapy and who achieve a sustained virological response experience a significant decline in ALT level, suggesting that their baseline ALT level was not truly normal (11). Because there is a wide variation in the laboratory normal ranges for ALT level, it is preferable, when calculating the true normal range, that results be expressed as a percentage of the upper limit of that laboratory normal. Finally, ALT level does not reflect fibrosis, but rather reflects inflammation. However, fibrosis, not inflammation, is the histological finding on which severity of disease and prediction of outcome is based.

Recommendation 5: Active viral hepatitis should be considered in men in whom the ALT level is more than 0.75 times the standard laboratory upper limit of normal and in women in whom the ALT level is more than 0.5 times the standard laboratory upper limit of normal. All laboratories should report these new normal ranges (II-2).

Recommendation 6: Normal ALT level does not exclude significant liver disease, and it does not correlate with ultimate outcome. Patients should not be denied treatment on the basis of normal ALT levels (II-1).

\section{HEPATITIS B}

\section{Epidemiology of HBV infection in Canada}

Chronic hepatitis B prevalence data are not collected by provincial and federal public health authorities. Although all positive hepatitis B surface antigen ( $\mathrm{HBsAg}$ ) tests are reported to local public health units, only test results associated with an acute infection are tracked. Positive tests that are a result of chronic hepatitis are not collated or reported. As a result, the prevalence of chronic hepatitis B in Canada is unknown. There have been no large-scale studies representative of the communities at risk to assess overall prevalence. Hepatitis B in Canada is largely a disease of immigrants, who bring with them the high prevalence of hepatitis B in their home countries. Because immigrants tend to choose to live in large, urban areas of Canada, any seroprevalence survey would have to take into account that hepatitis B is not uniformly distributed across the country.

There have been some attempts to estimate the number of infected individuals in Canada. Statistics Canada attempted to estimate the number of $\mathrm{HBV}$-infected individuals by assuming a $6 \%$ rate in immigrants, a $1 \%$ rate in Canadian-born individuals and a $4 \%$ rate in aboriginals. This calculation suggested that there were approximately 600,000 people in Canada infected with HBV (12). However, this may be an overestimate 
because the rate of $1 \%$ in the Canadian-born population seems high.

It is important to know the prevalence of chronic hepatitis B because the disease has a high mortality rate (20\% to $25 \%$ untreated) and requires complex algorithms for management. There are major resource implications. First, without knowing the prevalence of hepatitis $B$, no planning for resource allocation can be undertaken. Second, there is a reservoir of infected individuals in Canada, and as with any infectious disease, the risk to the general population - or, more specifically, to the populations in which hepatitis B is endemic - should be known.

Immigration continues to introduce additional HBV-infected individuals to Canada. The prevalence in recent immigrants is unknown. Recent data from New York suggest that $15 \%$ of recent immigrants from China and Korea are infected with HBV (13). This is likely to be true in Canada as well. Thus, rather than a decrease in the pool of infected patients as a result of vaccination, there is an increase as a result of immigration.

Recommendation 7: Chronic hepatitis B should be a notifiable disease, with appropriate records kept and appropriate risk factor information collected (III).

Recommendation 8: The Federal Ministry of Health and/or the provinces should develop seroprevalence surveys to determine the numbers of HBV-infected individuals in Canada and in each province (III).

\section{Hepatitis B vaccination policy in Canada}

The ideal vaccination policy against HBV is universal neonatal vaccination, with catch-up vaccination of adolescents who have not been vaccinated. Successive Canadian consensus conferences on the management of chronic viral hepatitis have recommended this policy. The National Advisory Committee on Immunization (NACI) has not adopted these recommendations. Many provinces in Canada still rely on maternal screening to identify at-risk babies who should be vaccinated, rather than universal neonatal vaccination. This ignores the reality in Canada that hepatitis B is a disease of immigrants, not all of whom are visible minorities, and ignores the possibility of fathers or other family members, rather than mothers, being infected. The current vaccination strategy has been accompanied by a decrease in acute hepatitis B in all age groups (including adults too old to have been included in adolescent vaccination strategies). Therefore, the decline in incidence is not entirely due to vaccination. Data from Quebec show that there is still a significant incidence of acute hepatitis B in children younger than 10 years (14). Approximately $25 \%$ of cases of acute hepatitis B in Quebec could be prevented by universal neonatal vaccination.

The 13 health care jurisdictions that administer hepatitis B vaccination in Canada have each developed their own infant and adolescent vaccination program. No two programs are identical. There is no scientific rationale to support these differences. This has the consequence that children who move from province to province run the risk of being excluded from the local vaccination program in both their home and their destination province.

Current vaccination practices for children of carrier mothers, or with a family member who is known to be a carrier, are appropriate, and should remain in place.
Recommendation 9: The ideal hepatitis B vaccination policy for Canada is universal infant vaccination and catch-up vaccination for those who did not receive adolescent vaccination (I).

Recommendation 10: The provinces should harmonize their hepatitis B vaccination programs and must

institute universal neonatal or infant vaccination (III).

Hepatitis $B$ vaccination is also recommended for patients who have chronic liver disease other than hepatitis B $(15,16)$ because patients with liver disease may not be able to sustain a second injury to the liver. The efficacy of vaccinating this population is not good. Only approximately $14 \%$ of patients with cirrhosis develop protective antibody levels (17). Nonetheless, this recommendation by NACI should remain. However, NACI also recommends hepatitis $B$ vaccination for all patients who are to be treated with hepatotoxic drugs. There is no scientific rationale for this recommendation. Most drugs are potentially hepatotoxic. Therefore, this recommendation will eventually apply to virtually everyone at some stage. The vast majority of hepatotoxic drug reactions are acute and self-limited in nature. It is hard to understand how hepatitis B vaccination might change the outcome of these reactions. The presence of liver disease is not a contraindication to most potentially hepatotoxic drugs because the vast majority of these reactions are idiosyncratic and are not more likely in patients who have preexisting liver disease of any cause. NACI is strongly urged to reconsider this recommendation. The consensus of the present meeting was that this recommendation should actively be opposed.

The meeting did support the NACI recommendations on vaccination of potential organ transplant recipients.

Recommendation 11: Hepatitis B vaccination is not required for patients who are exposed to potentially hepatotoxic drugs (III).

\section{Hepatitis B laboratory testing}

HBV DNA viral load testing: HBV DNA assays have undergone significant evolution in the past few years. In the past, assays lacked sensitivity, and were poorly standardized, poorly reproducible and reported in different units. This made interpretation and comparison among studies difficult. Recently, the HBV DNA International Unit per $\mathrm{mL}(\mathrm{IU} / \mathrm{mL}$ ) was adopted (18), leading to improved comparability among commercial assays. Newer assays are now usually polymerase chain reaction (PCR) based (19-21), with a wider dynamic range (concentration range over which the dose-response curve is linear) that allows accurate determination of the viral load in most patients (Figure 1). HBV DNA measurement is now a crucial tool in the evaluation of patients with hepatitis B. Indeed, it is not possible to properly manage hepatitis B patients without this assay. Furthermore, because it has become important to identify patients with undetectable HBV DNA in serum, the most sensitive assays available should be used. Currently, this is the Taqman PCR (Roche Molecular Systems Inc, USA), which has a lower limit of sensitivity of $6 \mathrm{IU} / \mathrm{mL}$ and a dynamic range that encompasses all clinically significant variations in viral load. Viral load measurements usually need to be repeated at three to six monthly intervals, and sometimes more frequently to confirm viral resistance. Therefore, there should be no restriction on the frequency of testing. 
Recommendation 12: Clinicians caring for hepatitis B patients should have ready access to HBV DNA testing for all patients. Reporting of results should be timely (within two weeks) and should include the dynamic range. Results should be reported in $\mathrm{IU} / \mathrm{mL}$ to allow for correlation among laboratories and with published studies. The most sensitive assay available should be used (II-3).

Throughout the present document, reference is made to 'high' and 'low' hepatitis B viral loads. The HBV DNA concentrations associated with these states are not clearly defined and vary in different circumstances. Therefore, when these terms are used, a range of HBV DNA concentrations are provided that would be considered appropriate by most. However, these are not separate conditions, and 'high' merges imperceptibly into 'low' HBV DNA concentrations.

HBV genotyping: There are currently eight recognized genotypes (A through $\mathrm{H}$ ) based on sequence variations of the HBV genome. Genotype A is common in Europe, North America and Africa. Genotypes B and C predominate in the Far East. Genotype D is found worldwide, genotype E occurs in Africa, genotype $\mathrm{F}$ is found in South America and Alaska, genotype $\mathrm{G}$ is seen in North America and genotype $\mathrm{H}$ occurs in Central America $(22,23)$.

Genotype B has been associated with less severe liver disease, lower rates of hepatitis $\mathrm{B}$ e antigen ( $\mathrm{HBeAg}$ ) reactivity and higher spontaneous $\mathrm{HBeAg}$ seroconversion than genotype C (24). Genotype D may be associated with a higher rate of hepatoma, and higher rates of post-transplant recurrence and mortality than genotype A (24). Genotypes C and D are associated with a lower response to interferon (IFN) than genotypes A and B (25). Various test methods are available for genotype determination, with sensitivity and specificity approaching $95 \%$ to $99 \%$. Although the clinical utility of genotype determination in individual patients remains to be defined, knowing the genotype may help to determine the choice of antiviral therapy.

Recommendation 13: Clinicians should have access to HBV genotype testing, which may help in the selection of antiviral therapy and prediction of response with

IFN-based therapy (II-3).

\section{Natural history of chronic HBV infection}

Hepatitis B is an indolent disease that seldom causes symptoms until complications of cirrhosis and liver cancer occur. However, HBV infection is associated with an excess mortality, mainly from hepatocellular carcinoma (HCC), as well as cirrhosis and its complications, which may reach $458 / 100,000$ per year (26).

The natural history of HBV infection is thought to evolve through four phases (Table 2) (27). Not all patients go through

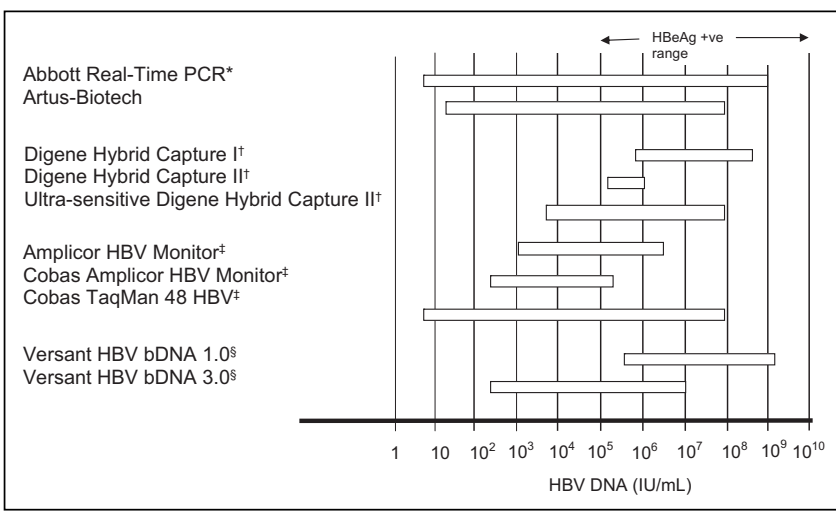

Figure 1) Dynamic range of assays for hepatitis B virus (HBV) DNA. High concentration samples require dilution and retesting. *Abbott Molecular Inc, USA; ${ }^{\dagger}$ Digene Corporation, USA; ${ }^{\star}$ Roche Molecular Systems, USA; ${ }^{\S}$ Bayer Healthcare, USA. HBeAg +ve Hepatitis B e antigen positive; PCR Polymerase chain reaction

every phase. In perinatal or childhood infection, the immune tolerant phase may last for fewer than 10 years or more than 20 years. Strictly speaking, the definition of the immune tolerant phase includes a liver biopsy with no or minimal inflammation. In practice, biopsies are seldom used to diagnose this phase, so most rely on the ALT level. As patients get older, the likelihood of liver injury increases, despite an apparently normal ALT level. This is because inflammation may be mild and intermittent ALT testing may miss shortlived periods of elevated ALT. Complicating the diagnosis of the immune tolerant phase is that the ALT level can be intermittently normal during the immune clearance phase. Thus, when a patient apparently meeting the criteria (Table 2) for the immune tolerant phase is initially seen, close follow-up is necessary to determine whether the ALT level might become elevated, signifying that either the immune clearance phase is starting or the patient was in the immune clearance phase all the time.

The immune clearance phase may last a variable period of time, ranging from fewer than five years to more than 25 years, and is terminated by seroconversion from $\mathrm{HBeAg}$-positive to anti-HBe-positive. Predictors of seroconversion are a high ALT level, a low HBV DNA level, age younger than 40 years and absence of cirrhosis $(28,29)$. These factors also identify patients who are more likely to seroconvert on therapy. Seroconversion, whether spontaneous or treatment-induced, is almost invariably associated with initial remission of disease activity and normalization of ALT (30). In some patients, this inactivation is permanent, and these patients become inactive carriers. Thus, in the short term, patients who seroconvert are associated with improved outcomes compared with patients

\section{TABLE 2}

Phases of hepatitis B virus (HBV) infection

\begin{tabular}{llllll}
\hline Phase & HBsAg & HBeAg & Anti-HBe & ALT pattern & HBV DNA range \\
\hline Immune tolerant & Positive & Positive & Negative & Normal & Approximately greater than $2 \times 10^{4} \mathrm{IU} / \mathrm{mL}$ to greater than $2 \times 10^{8} \mathrm{IU} / \mathrm{mL}$ \\
Immune clearance & Positive & Positive & Negative & Normal or elevated & Approximately greater than $2 \times 10^{4} \mathrm{IU} / \mathrm{mL}$ to greater than $2 \times 10^{8} \mathrm{IU} / \mathrm{mL}$ \\
Inactive disease & Positive & Negative & Positive & Normal & Less than $200 \mathrm{IU} / \mathrm{mL}$ \\
HBeAg-negative chronic hepatitis B & Positive & Negative & Positive & Normal or elevated & Undetectable to greater than $2 \times 10^{8} \mathrm{IU} / \mathrm{mL}$ \\
Resolved HBV infection & Negative & Negative & Positive & Normal & Undetectable \\
\hline
\end{tabular}

ALT Alanine aminotransferase; HBeAg Hepatitis B e antigen; HBsAg Hepatitis B surface antigen 


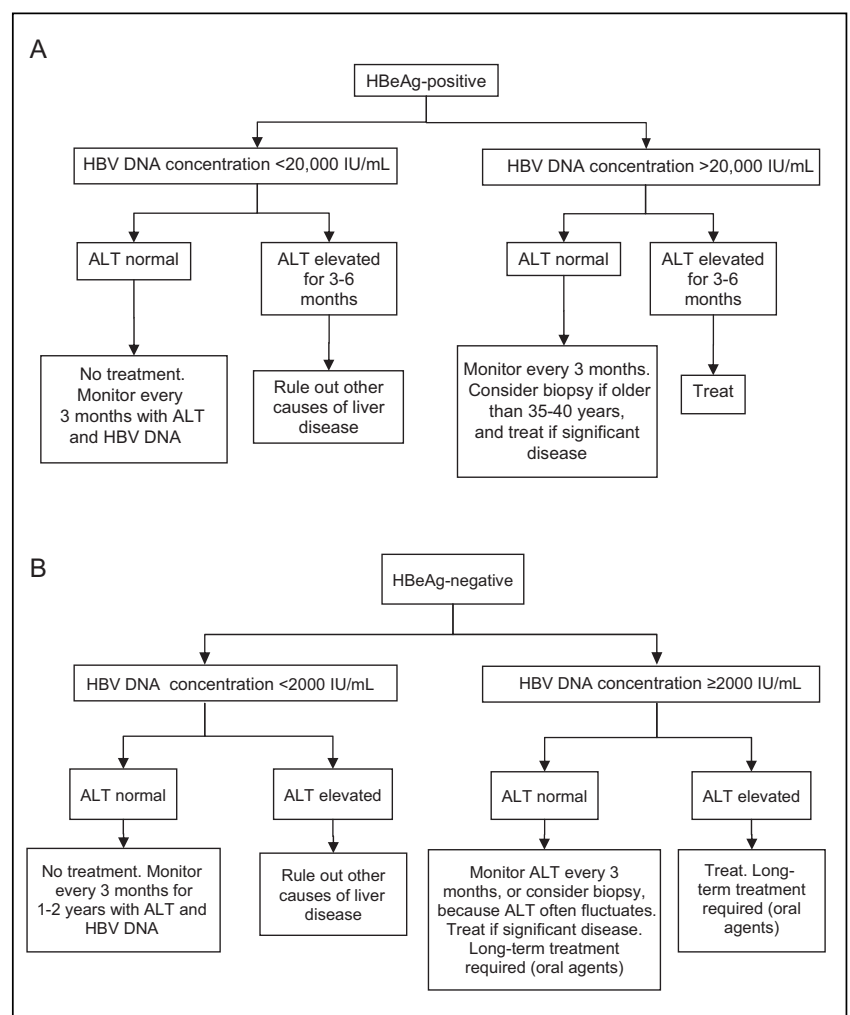

Figure 2) A Algorithm for selecting hepatitis $\mathrm{B}$ e antigen ( $\mathrm{HBeAg}$ )positive patients for treatment. B Algorithm for selecting $\mathrm{HBeAg-}$ negative patients for treatment. ALT Alanine aminotransferase; HBV Hepatitis $B$ virus

who do not seroconvert. However, over the longer term, there is a risk for reactivation to the HBeAg-negative chronic hepatitis B state (see below).

The inactive carrier state is characterized by a lack of $\mathrm{HBeAg}$, presence of anti-HBe, persistently normal ALT level, and low (less than $2000 \mathrm{IU} / \mathrm{mL}$ ) or undetectable levels of HBV DNA (Table 2) (3). The inactive carrier state does not preclude the presence of significant disease, including cirrhosis. Whether cirrhosis is present or not depends on the amount of inflammation present before seroconversion. However, in the inactive state, there is little or no inflammation, and fibrosis does not progress. Patients who seroconvert before the development of major fibrosis are probably at low risk for HCC. However, patients who develop cirrhosis before seroconversion continue to have a high risk of HCC. It is important to recognize that cirrhosis can regress over time; thus, a biopsy performed years after either spontaneous or treatment-induced inactivation of disease may show minimal fibrosis. Careful histological evaluation may show evidence of regressed cirrhosis. In these patients, the risk of HCC remains. Seroreversion to HBeAg-positive can occur and is usually associated with reactivation of hepatitis (29).

Some anti-HBe-positive patients may continue to have HBV DNA concentrations in the range that may be associated with disease. Other patients may have inactive disease for variable periods of time (up to many years) but eventually develop active disease again, despite being anti-HBe-positive. This is classified as HBeAg-negative (or anti-HBe-positive) chronic hepatitis B. Thus, a single finding of a normal ALT level and a HBV DNA level below $2000 \mathrm{IU} / \mathrm{mL}$ does not prove the diagnosis of the inactive carrier state. Only prolonged close follow-up and persistence of these markers of inactivity provide a confident diagnosis of the inactive carrier state, rather than a transient remission of $\mathrm{HBeAg}$-negative chronic hepatitis $\mathrm{B}$.

HBeAg-negative chronic hepatitis B is most often seen in patients after a variable duration of the inactive carrier state, but some may progress directly from $\mathrm{HBeAg}$-positive chronic hepatitis to HBeAg-negative chronic hepatitis (31). This means that even patients who have apparently had inactive disease for years must continue to be followed for the possibility of reactivation.

The risks for cirrhosis and HCC development are multifactorial, but are correlated with the degree and severity of chronic inflammation, older age, male sex, concomitant causes of liver injury (ie, coinfection with HCV or alcohol abuse) and HBV DNA levels (see later) (32-36). Chronic hepatitis progresses to cirrhosis at an estimated rate of $2 \%$ to $10 \%$ per year $(37-39)$. Subsequent evolution to decompensated cirrhosis or HCC occurs at a rate of $5 \%$ to $10 \%$ per year, with an annual death rate of $20 \%$ to $50 \%$ in these patients. Spontaneous natural clearance of HBsAg occurs in only $0.5 \%$ to $0.8 \%$ of chronic carriers per year $(40,41)$.

\section{Evaluation of the $\mathrm{HBV}$-infected patient}

The initial assessment of all HBsAg-positive patients should include a detailed history, including family history of hepatitis and HCC, risk factors for hepatitis B acquisition and alcohol use. A physical examination should be performed to detect signs of chronic liver disease and liver decompensation. Laboratory testing should include serum ALT or aspartate aminotransferase, alkaline phosphatase, bilirubin, albumin, creatinine, international normalized ratio and complete blood count. Specific HBV testing should include $\mathrm{HBsAg}, \mathrm{HBeAg}$, anti-HBe and serum HBV DNA quantitation. This should be performed in all patients at first assessment. If available, the genotype should be obtained. Resistance genotyping should also be done for patients who have had prior treatment with nucleoside analogues and who are currently off treatment (see later). Screens for comorbid conditions should include antiHCV and anti-HIV. Anti-hepatitis D virus (HDV) testing should be performed in those with past or current intravenous drug use, those with a sexual history with a past or present injection drug user, or those who come from geographical regions endemic for HDV. Anti-HDV testing should also be performed in patients with chronic hepatitis $\mathrm{B}$ who have an elevated ALT level and a low to undetectable HBV DNA concentration. An exact cut-off for a low HBV DNA concentration has not been defined, but in this instance, it is probably below $2000 \mathrm{IU} / \mathrm{mL}$. A baseline abdominal ultrasound should be performed to detect obvious signs of cirrhosis or portal hypertension, and presence of hepatoma. (Note that ultrasound does not detect mild degrees of cirrhosis.)

Liver biopsy: Liver biopsy is currently the only method to assess the extent of fibrosis to diagnose early cirrhosis and to identify coexisting liver diseases. In the past, a liver biopsy was usually recommended in patients with active viral replication and an elevated ALT level. It is now appreciated that the normal ranges of serum ALT and aspartate aminotransferase provided by most laboratories are too high (see earlier), and significant histological damage may be present in 13\% to $43 \%$ of patients with 'normal' liver enzymes (6-10). Hence, a liver biopsy may aid in the assessment of the patient for antiviral therapy. The patient selection algorithm provided in Figure 2 
indicates that it is acceptable and often necessary to perform a biopsy in patients with a normal ALT level. Indeed, in some patients, this may be the only method for determining the presence of liver disease. A liver biopsy may not be needed if there are clinical, laboratory or radiological findings to suggest cirrhosis. Recent developments in noninvasive testing for fibrosis, such as FibroTest (BioPredictive, France) or FibroScan (EchoSens, France), may eventually decrease the need for biopsy, but these tests lack the ability to assess inflammation or coexisting diagnoses and require additional validation.

HIV testing: Hepatitis B and HIV are acquired by the same transmission routes. Many HBV endemic areas also have high rates of HIV, with heterosexual contact as the major risk factor. There is a general move to more widespread testing for HIV because patients may not disclose risk factors. Many of the nucleoside analogues used to treat hepatitis $\mathrm{B}$ are also active against HIV. The impact of monotherapy on HIV resistance means that all patients with HBV should be screened for HIV.

Recommendation 14: All patients infected with HBV should be tested for HIV infection, with appropriate pre- and post-test counselling (II-2).

\section{Selection of patients for treatment}

The objective of treatment in chronic hepatitis B is to prevent the development of cirrhosis and its consequences, liver failure and HCC. However, not all HBV-infected patients are destined to develop these complications. The challenge is to identify those who are at risk for the development of these adverse consequences and to offer them treatment. Conversely, identifying those who will not progress may spare some patients unnecessary treatment. At present, the tools available to do this are rudimentary. The factors that have been identified as indicating risk of adverse outcomes include the HBV DNA concentration, age, fibrosis on histology and ALT level (8,33-36,41,42). Of these, HBV DNA concentration has been best studied. There are now several large-scale, long-term, prospective studies (33-36) that have correlated HBV DNA concentration at recruitment with outcome. These studies have all come to the same conclusion: the risk of developing cirrhosis and HCC, and the risk of dying from these conditions, increases with higher HBV DNA concentrations at recruitment and with persistence of high HBV DNA concentrations. However, in considering the role of HBV DNA concentration as a marker of prognosis, it is important to be aware of the nature of the populations examined in these studies. The studies did not include patients younger than 25 years, and the number of patients younger than 30 years was small. The proportion of anti-HBe-positive patients ranged from approximately $50 \%$ to approximately $80 \%$. Thus, in patients older than 30 years, and in particular in those who are anti-HBe-positive, HBV DNA concentration is a good predictor of risk of adverse outcomes. This is also likely to be true in patients older than 30 to 40 years who are $\mathrm{HBeAg}$-positive. However, this is not the case in younger patients. The studies also showed a correlation between ALT level and outcome, but the association was not as strong as for HBV DNA concentration. In particular, patients with an ALT level within the laboratory normal range were also at risk for the development of cirrhosis and HCC if the HBV DNA concentration was higher than $10^{4}$ copies $/ \mathrm{mL}$ (approximately $2000 \mathrm{IU} / \mathrm{mL}$ ). This reinforces the concept that it is no longer defensible to exclude patients with normal ALT levels from therapy. However, to reduce the likelihood of treating patients who may never develop significant liver disease, if the HBV DNA concentration is high and the ALT level is normal, there should be other indicators of significant liver disease before starting therapy. These may come from ultrasound evidence of cirrhosis, or biopsy evidence of at least moderate fibrosis or inflammation. Transient ALT level elevations, particularly if mild, may not be associated with significant disease. However, prolonged ALT level elevation is more likely to be associated with significant injury. Thus, contrary to previous practice, biopsy of patients with normal ALT levels may be required to determine the presence of liver disease and to make a treatment decision.

In summary, the decision to treat requires the consideration of several factors: patient age, the level of viral replication, $\mathrm{HBeAg}$ status, and evidence of significant liver disease in the form of prolonged elevation of ALT level, fibrosis or inflammation on biopsy, or ultrasound evidence of cirrhosis.

For HBeAg-positive patients, treatment should be considered if the HBV DNA concentration is higher than 20,000 IU/mL. HBeAg-positive patients with lower concentrations of HBV DNA may be in the process of seroconverting. For $\mathrm{HBeAg}$-negative patients, treatment should be considered if the HBV DNA concentration is higher than $2000 \mathrm{IU} / \mathrm{mL}$ because studies have suggested that severe outcomes are uncommon if the HBV DNA concentration is below that level $(34,35)$. Although liver injury is uncommon if the HBV DNA concentration is below $2000 \mathrm{IU} / \mathrm{mL}$, some patients may have HBV-induced liver disease at lower viral loads. A biopsy is helpful to exclude alternative diagnoses and to confirm the picture of viral-induced injury. Furthermore, the HBV DNA concentration may fluctuate and, thus, repeat measurements are required. An HBV DNA measurement higher than $2000 \mathrm{IU} / \mathrm{mL}$ is diagnostic of $\mathrm{HBeAg}$-negative chronic hepatitis $B$ and suggests that the patient may need treatment because $\mathrm{HBeAg}$-negative hepatitis $\mathrm{B}$ is associated with more advanced and progressive liver disease, and never completely remits spontaneously. However, in individual patients, the severity of underlying liver disease is unpredictable, and thus, a biopsy may be necessary.

Young adults who are $\mathrm{HBeAg}$-positive usually have very high viral loads (greater than $10^{7} \mathrm{IU} / \mathrm{mL}$ ), with variable ALT levels $(43,44)$. Most often, these individuals have no or minimal liver disease on biopsy. Immediate treatment may not be necessary, even with an elevated ALT level. It is impossible to predict whether these individuals will undergo seroconversion with remission of disease before the development of significant liver injury. In these patients, high viral loads do not carry the same implications for outcome as in older patients. Treatment can be withheld in the hope of seroconversion. However, these patients must be closely monitored because they may develop more severe disease. Thus, not every HBeAg-positive patient with an elevated ALT level needs treatment. Figure 2 provides an algorithm for identifying individual patients who may need treatment.

Recommendation 15: HBeAg-positive patients in whom the HBV DNA concentration is higher than 20,000 IU/mL with an elevated ALT level should be considered for treatment. Patients with significant inflammation or fibrosis on biopsy should also be treated, even if the HBV DNA concentration is lower than $20,000 \mathrm{IU} / \mathrm{mL}$ or the ALT level is normal (II-1). 


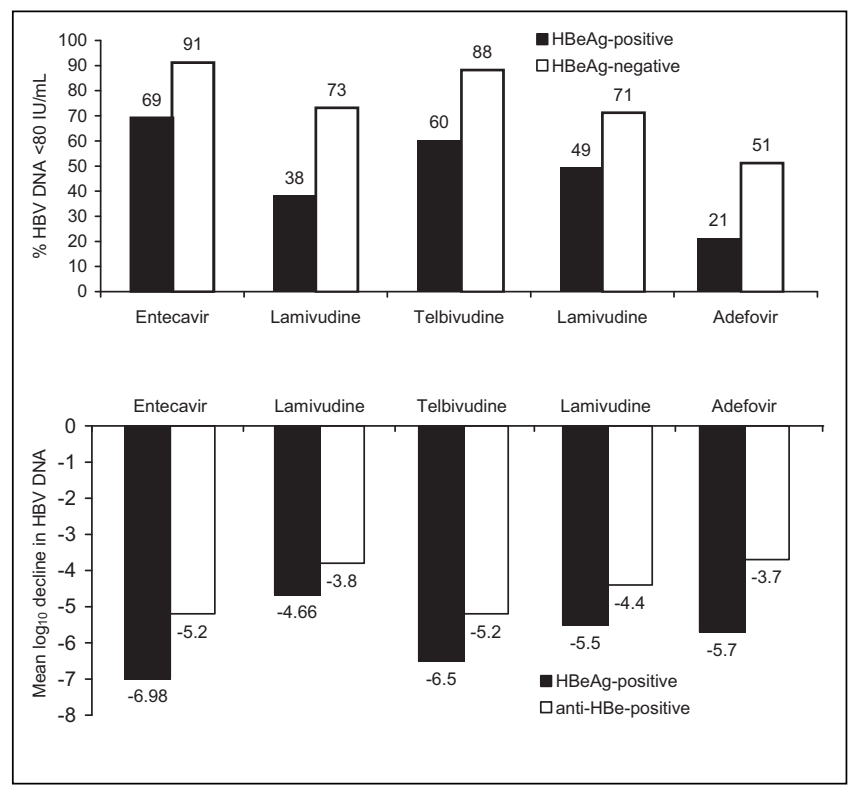

Figure 3) Relative potencies of different hepatitis B antivirals at 48 to 52 weeks of therapy. Lamivudine has been compared with entecavir and to telbivudine in two separate randomized controlled trials $(73,88)$. Adefovir has not been compared directly with the other agents. HBeAg Hepatitis B e antigen; HBV Hepatitis B virus. Data from references $73,81,98,160$ and 161

\section{Recommendation 16: $\mathrm{HBeAg}$-negative patients in whom the HBV DNA concentration is higher than $2000 \mathrm{IU} / \mathrm{mL}$ with an elevated ALT level should be considered for treatment. Patients with significant inflammation or fibrosis on biopsy should also be treated, even if the HBV DNA concentration is lower than $2000 \mathrm{IU} / \mathrm{mL}$ or the ALT level is normal (II-1).}

\section{Drugs to treat hepatitis B and their use}

The next section provides information on the individual drugs available to treat hepatitis B. A comparison of the efficacy of the different agents is provided in Figure 3 and Table 3.

IFNs: IFNs have both antiviral and immunomodulatory properties, which make them effective at inducing $\mathrm{HBeAg}$ seroconversion. Potential advantages of IFNs over nucleoside analogues include the absence of resistance mutations and a shorter fixed duration of therapy. The major disadvantages, however, are the numerous adverse effects and the route of administration (subcutaneous injection).

HBeAg-positive chronic hepatitis B: $\mathrm{HBeAg}$ seroconversion occurs in $25 \%$ to $40 \%$ of treated patients (45-49). IFN is generally less effective at inducing $\mathrm{HBeAg}$ seroconversion in patients with high viral loads. The studies that demonstrated this were performed using assays of limited sensitivity, and the results are difficult to translate into IU/mL. However, IFN is less effective in patients in whom the HBV DNA concentration is greater than $2 \times 10^{7} \mathrm{IU} / \mathrm{mL}$. Seroconversion rates are also reduced in those with low ALT levels (less than two times the upper limit of laboratory normal) and, therefore, IFNs are not recommended for the treatment of patients with a high viral load or a low ALT level. Other predictors of poor response include age over 40 years, male sex and cirrhosis. IFNs are contraindicated in decompensated cirrhosis, but can be used in patients with fully compensated cirrhosis (normal albumin, international normalized ratio and bilirubin, and no significant
TABLE 3

Hepatitis $B$ e antigen ( $\mathrm{HBeAg}$ ) seroconversion rates with hepatitis $B$ antiviral therapy

\begin{tabular}{|c|c|c|}
\hline & Duration of treatment & $\begin{array}{c}\text { HBe seroconversion rate } \\
\text { (reference) }\end{array}$ \\
\hline Standard interferon & 16 to 24 weeks & $33 \%$ (HBeAg loss) (49) \\
\hline Pegylated interferon & 24 to 48 weeks & $29 \%$ to $32 \%(29,55,56)$ \\
\hline \multirow[t]{2}{*}{ Lamivudine } & One year & $17 \%$ to $20 \%(70-73)$ \\
\hline & Three years & $40 \%(76)$ \\
\hline \multirow[t]{2}{*}{ Adefovir } & One year & $12 \%(78)$ \\
\hline & Three years & $43 \%(80)$ \\
\hline \multirow[t]{2}{*}{ Entecavir } & One year & $21 \%(73)$ \\
\hline & Three years & $39 \%(87)$ \\
\hline \multirow[t]{2}{*}{ Telbivudine } & One year & $22 \%(90)$ \\
\hline & Two years & $33 \%(91)$ \\
\hline
\end{tabular}

portal hypertension). Response rates in cirrhosis are low. Treatment of patients with decompensated cirrhosis with IFN should only be considered in special circumstances (eg, multidrug resistance) and in specialized treatment centres. Standard IFN is given at a dose of 10 million international units (MIU) three times per week or 5 MIU daily subcutaneously for 16 to 24 weeks (45-49). IFN-induced HBeAg seroconversion is durable in $70 \%$ to $80 \%$ of patients, with up to eight years of follow-up (50-54). Delayed HBsAg clearance occurs more frequently in IFN-treated patients than in untreated control subjects; however, this is only seen in a minority of patients (approximately 6\% to 8\%) (53).

Pegylated IFN (PEG IFN)-alpha-2a (180 $\mu$ subcutaneously once weekly) is approved for the treatment of hepatitis B. PEG IFN-alpha-2b has been submitted for approval for the hepatitis B indication. Two studies $(55,56)$ evaluated PEG IFNalpha-2a in chronic hepatitis B. The first study (55) compared 24 weeks of PEG IFN-alpha-2a with 24 weeks of standard IFN. The dose of standard IFN used in the study would be considered inadequate in North America (55). This study showed that PEG IFN (180 $\mu \mathrm{g}$ dose) induced HBeAg seroconversion in $28 \%$ of subjects versus $12 \%$ of subjects with standard IFN. The second study (56) looked at the use of PEG IFN with or without lamivudine for 48 weeks. In the study, the $\mathrm{HBeAg}$ seroconversion rate was similar to that seen in the 24-week study, at $32 \%$. An additional study (25), using a similar design, evaluated PEG IFN-alpha-2b with or without lamivudine for 48 weeks and found an HBeAg seroconversion rate of $29 \%$. Thus, it is not certain whether 48 weeks of PEG IFN therapy is superior to 24 weeks of PEG IFN therapy. It has also not been clearly established whether 24 or 48 weeks of PEG IFN is superior to 16 to 24 weeks of standard IFN at adequate doses.

The addition of lamivudine to IFN-based therapies offers no advantage. The role of other nucleoside analogues in combination with IFNs requires further study.

IFN-induced $\mathrm{HBeAg}$ seroconversion is associated with improved overall survival and complication-free survival (57-59). There are conflicting data on the impact of IFN therapy on the incidence of HCC, although most reports (57-59) conclude that the incidence of HCC is reduced. Similar evidence for nucleoside analogue-treated patients has not yet been obtained. HBeAg-negative chronic hepatitis B: The response rates to standard IFN in HBeAg-negative patients are inferior to and less durable than those achieved in $\mathrm{HBeAg}$-positive patients. The 
assays used to define response in studies of standard IFN were insensitive compared with tests available today. Therefore, it is not clear whether patients defined as having negative HBV DNA by these assays were truly negative or whether they would still be considered as having relapsed if today's assays were used. It is, therefore, impossible to compare those results with current results using PEG IFN.

PEG IFN-alpha-2a given for 48 weeks is effective therapy in HBeAg-negative patients. Responses are less durable than those achieved in HBeAg-positive patients. PEG IFN-alpha-2a given at $180 \mu \mathrm{g}$ subcutaneously once weekly for 48 weeks results in suppression of HBV DNA concentrations to below 20,000 copies $/ \mathrm{mL}$ (approximately $4000 \mathrm{IU} / \mathrm{mL}$ ) in $43 \%$ of patients on therapy (60). However, only $19 \%$ continue to have undetectable HBV DNA concentrations 24 weeks after stopping therapy. PEG IFN and standard IFN have not been compared directly in HBeAg-negative patients. However, at equivalent cost, a weekly injection seems preferable to daily or three times weekly injections.

Lamivudine: Lamivudine is a pyrimidine nucleoside analogue that inhibits binding of nucleosides to the HBV polymerase. The standard dose is $100 \mathrm{mg} /$ day (61). Lamivudine was the first oral agent to be approved in the treatment of HBV in Canada, and until 2006, it was the only such agent available. Thus, a large proportion of treated HBV patients are currently on this agent or have received it in the past. Generally, lamivudine is effective at lowering HBV viral load, and experience acquired over many years of its use in the treatment of hepatitis B and HIV has established its safety (62). The relative potency of lamivudine compared with other antivirals is shown in Figure 3. However, HBV becomes resistant to lamivudine, with the prevalence of lamivudine resistance approaching $70 \%$ at four years (63). Furthermore, the development of lamivudine resistance also increases the likelihood of resistance to other antiviral agents, and may compromise the response to other drugs, including adefovir, entecavir and telbivudine (64). Therefore, lamivudine is no longer a suitable first-line choice for the treatment of hepatitis B, although there are still some patients and some situations for whom lamivudine can be used; these are described below. The consensus was that lamivudine should continue to be recommended as a first-line agent for the treatment of hepatitis B only because of its cost advantage. However, lamivudine should only be used under circumstances that limit the development of resistance (see below).

Lamivudine has been shown to improve the outcome of HBV infection in patients with cirrhosis (65). At present, there is no high-level evidence that lamivudine (or other nucleoside analogues) improves survival. However, such data will likely never be available from high-quality studies because it is no longer considered ethical or practical to randomly assign patients to receive no treatment. Therefore, the evidence of efficacy of lamivudine comes from studies that are less rigorous. Patients with cirrhosis who are treated with lamivudine have slower progression of disease than untreated patients (65). This benefit is lost if lamivudine resistance develops, implying that it is the suppression of viral replication that mediates the response. Patients with cirrhosis who develop lamivudine resistance have worse survival than those whose infection remains sensitive to lamivudine (66), again suggesting that the improvement in outcome is mediated through viral suppression. There are also data suggesting that improvement in histology following antiviral therapy is correlated with the degree of viral suppression, rather than with any specific agent (67). Although these improved outcomes have mainly been demonstrated with lamivudine, any agent that induces viral suppression is expected to have the same effect.

Because the consequences of developing lamivudine resistance can be dire, lamivudine has to be used under circumstances that will prevent or at least minimize the development of resistance. Factors that predict the development of antiviral resistance in general and lamivudine resistance specifically include high baseline viral load $(68,69)$ and incomplete suppression of viral replication after six months of treatment. Therefore, lamivudine should not be used in patients with high viral loads (greater than $2 \times 10^{6} \mathrm{IU} / \mathrm{mL}$ ). Furthermore, studies have shown that failure to suppress virus adequately (below $60 \mathrm{IU} / \mathrm{mL}$ at 24 weeks) is associated with high levels of resistance over time (69).

HBeAg-positive chronic hepatitis B: HBeAg seroconversion can be expected in approximately $20 \%$ of patients at one year, rising to approximately $40 \%$ after three years (Table 3$)$ (70-73). The durability of seroconversion induced by lamivudine is not as good as the durability of seroconversion induced by IFN (approximately $50 \%$ to $70 \%)(74,75)$. These results may be improved with a period of consolidation therapy of six to 12 months beyond seroconversion (75). This is probably required for all nucleoside analogues.

HBeAg-negative chronic hepatitis B: Patients with $\mathrm{HBeAg-}$ negative chronic hepatitis $B$ require long-term therapy. Lamivudine is not a good choice for long-term therapy because of the high risk of resistance $(63,76)$. However, in patients in whom the baseline viral load is low (in the range of $2 \times 10^{4} \mathrm{IU} / \mathrm{mL}$ to $2 \times 10^{5} \mathrm{IU} / \mathrm{mL}$ ), lamivudine can be considered as long as response is assessed at six months; if the HBV DNA is still detectable, treatment should be changed to a more potent nucleoside analogue (69). Resistance testing should be done to determine the future choice of antiviral therapy. Patients currently on lamivudine who have undetectable levels of virus and who have been stable for some time do not need to have their therapy changed.

Other indications for lamivudine are described below. Adefovir: Adefovir dipivoxil is a purine nucleotide analogue. The standard dose is $10 \mathrm{mg} /$ day. Adefovir is not a highly potent agent and does not achieve complete viral suppression in the majority of patients within the first year (see Figure 3), but it has a relatively high genetic barrier to resistance. As with lamivudine, the risk factors for adefovir resistance are a high baseline viral load and inadequate suppression of virus on therapy (77). Therefore, adefovir should not be used in patients with high viral loads. In addition, an inadequate response defined as an HBV DNA concentration greater than $200 \mathrm{IU} / \mathrm{mL}$ after 48 weeks requires a change in treatment regimen (77). Failure to achieve this level of control is associated with significant rates of viral resistance. Resistance testing should be performed to determine future choices of therapy. Assuming no resistance, almost any other agent can be substituted for adefovir.

Adefovir is the drug of choice for patients with lamivudine resistance provided that adefovir is added early after the initial development of resistance (see later).

There is potential drug toxicity from adefovir use. Hypophosphatemia is common but does not appear to have 
any clinical consequences, such as metabolic bone disease. Nephrotoxicity in the form of an elevated creatinine level has been reported (78). Therefore, renal function (estimated glomerular filtration rate) should be monitored at baseline and at three monthly intervals during therapy. Potentially nephrotoxic drugs (eg, nonsteroidal anti-inflammatory drugs) should be avoided when possible because there is a possibility of potentiation of nephrotoxicity. Fanconi syndrome has also been reported. All of these effects are reversible if detected early but may not reverse if drug withdrawal is delayed.

$\mathrm{HBeAg}$-positive chronic hepatitis $\mathrm{B}$ : The $\mathrm{HBeAg}$ seroconversion rate in the first year is approximately $12 \%$ (78), but over time, the on-treatment $\mathrm{HBeAg}$ seroconversion rate increases to approximately 40\% (Table 3) (79). Seroconversion is durable in more than $90 \%$ of patients (79). Resistance rates in HBeAgpositive patients, who generally have a higher viral load than do HBeAg-negative patients, have not been described, but they are likely to be higher than those in the HBeAg-negative population.

$\mathrm{HBeAg-negative} \mathrm{chronic} \mathrm{hepatitis} \mathrm{B:} \mathrm{Despite} \mathrm{the} \mathrm{lack} \mathrm{of} \mathrm{potency,}$ five-year follow-up data for HBeAg-negative patients on adefovir show that complete viral suppression and normalization of ALT level is achievable in $50 \%$ to $60 \%$ of patients (80). The data indicate that the viral load falls progressively over time, with an improvement in histology. Genotypic adefovir resistance occurs in approximately $29 \%$ of patients after five years (80). Because of its resistance profile, adefovir is suitable for long-term use, provided that the initial response within the first year is adequate (see above).

Entecavir: Entecavir is a selective guanosine analogue and is the most potent inhibitor of HBV DNA replication currently available. It has been shown to suppress viral replication more effectively than lamivudine in treatment-naïve patients in both HBeAg-positive (73) and HBeAg-negative (81) subjects, and it may be an effective therapy for some $\mathrm{HBeAg-}$ positive patients with resistance to lamivudine (82). Entecavir was well tolerated and had a similar side effect profile to lamivudine. However, the long-term safety has not yet been established. In treatment-naïve subjects, only approximately $1 \%$ of subjects developed resistance to entecavir after three years $(83,84)$. However, this is not the case for patients with prior lamivudine resistance. Resistance to entecavir requires the presence of the YMDD mutations that confer resistance to lamivudine, and also requires the presence of one of two or three additional mutations (85). These additional mutations, if present without the YMDD mutations, do not confer resistance to entecavir. Therefore, lamivudine resistance predisposed to entecavir resistance, and after three years of therapy, approximately $32 \%$ of lamivudine-resistant entecavirtreated patients had developed resistance to entecavir (86). Entecavir should be used to treat lamivudine-resistant infection only when no other alternative is available to treat lamivudine resistance.

The standard dose of entecavir is $0.5 \mathrm{mg} /$ day. The dose in lamivudine-resistant patients is $1 \mathrm{mg} /$ day. However, the $1 \mathrm{mg}$ tablet has not been approved in Canada. Failure to achieve undetectable virus in the first year does not require a change in therapy, except in the case of primary nonresponse, because by the end of year 3, more than $80 \%$ of patients will be HBV DNA negative and selection of resistant mutants is uncommon. Published cost-efficacy data for entecavir suggest that its use is cost-effective, particularly in patients with cirrhosis (86).
HBeAg-positive chronic hepatitis B: The expected rates of $\mathrm{HBeAg}$ seroconversion at one year are similar to those of other nucleoside analogues at 21\% after year 1 and $39 \%$ after year 3 (Table 3) (73,87). The HBeAg seroconversion persists in approximately $80 \%$ of patients 24 weeks after withdrawing treatment. However, persistent off-therapy suppression of virus to undetectable levels occurs in only approximately $75 \%$ of cases. $\mathrm{HBe} A g$-negative chronic hepatitis B: Entecavir is a good choice for these patients because of the favourable resistance profile (84). On withdrawal of therapy, most patients relapse, again indicating the need for long-term treatment.

Telbivudine: Telbivudine is a pyrimidine nucleoside analogue with potent antiviral efficacy against HBV. Telbivudine suppresses HBV replication more effectively than lamivudine in patients with $\mathrm{HBeAg}$-positive and $\mathrm{HBeAg}$-negative chronic hepatitis B. The standard dose of telbivudine is $600 \mathrm{mg}$ daily $(88,89)$. Genotypic resistance rates of $5 \%$ and $11 \%$ were reported after one and two years of telbivudine treatment, respectively (89). Telbivudine was generally well tolerated. An asymptomatic increase in creatine kinase occurred in approximately $12 \%$ of patients. Symptomatic myositis has also been described.

Telbivudine is more potent than lamivudine and can be used in patients with high viral loads. However, as with lamivudine, inadequate suppression of virus is associated with significant rates of development of resistance. Therefore, if after six months of therapy, the HBV DNA concentration is still above $60 \mathrm{IU} / \mathrm{mL}$, a change in therapy is needed to reduce the risk of developing resistance (90). Resistance testing should be performed to determine future choices of therapy. $\mathrm{HBeAg}$-positive chronic hepatitis B: Seroconversion will occur in approximately $22 \%$ in the first year, rising to approximately $33 \%$ in the second year of treatment $(90,91)$. However, efficacy needs to be checked at six months, and if the viral load is greater than $60 \mathrm{IU} / \mathrm{mL}$, treatment should be changed.

HBeAg-negative chronic hepatitis B: Telbivudine is suitable for use in patients with $\mathrm{HBeAg-negative} \mathrm{chronic} \mathrm{hepatitis} B$ because it has a good resistance profile. However, efficacy needs to be checked at six months, and if the viral load is greater than $60 \mathrm{IU} / \mathrm{mL}$, treatment should be changed.

Tenofovir: Tenofovir is a purine analogue that has been licensed for treatment of HIV but not hepatitis B. However, it has potent activity against hepatitis B. Its efficacy has been demonstrated in small studies $(91,92)$ in patients who either were resistant to adefovir or had an initial inadequate response to lamivudine, as well as in a study (93) in HIV-coinfected patients. These studies showed that viral suppression was rapid and potent. To date, resistance has only rarely been described, but adequate studies are lacking (94). Because tenofovir is not licensed for hepatitis $B$, no recommendations can be made about its use as a first-line therapy. However, in the setting of patients with an inadequate response to adefovir or resistance to both adefovir and lamivudine, it seems to be an effective antiviral. Tenofovir is also a drug of choice in HBV-HIV coinfection as part of highly active antiretroviral therapy (HAART). Emtricitabine: Emtricitabine (FTC) has recently been licensed in Canada for HIV in combination with tenofovir. It has been used in studies to treat hepatitis B $(95,96)$, but it is not licensed for that purpose. Emtricitabine is a pyrimidine nucleoside analogue, with an activity spectrum and a resistance spectrum that are very similar to those of lamivudine. Emtricitabine is not available as monotherapy. 
De novo combination therapy: Although combination therapy for hepatitis B may be appropriate, there are little data to support its use. In a single study (97), a combination of lamivudine and adefovir was compared with lamivudine alone. There was no difference in HBV DNA suppression, HBeAg seroconversion or ALT level normalization. Resistance to lamivudine was not completely prevented. The combination of lamivudine and telbivudine was less effective than telbivudine alone for all end points (98). In patients with cirrhosis, particularly those with some degree of hepatic decompensation, the development of resistance to antiviral agents may be associated with a potentially fatal flare of disease activity. Therefore, in this setting, combination therapy can be considered. Suggested combinations are lamivudine and adefovir, tenofovir and lamivudine or emtricitabine, or entecavir and adefovir or tenofovir. Entecavir monotherapy may also be suitable in these patients.

Figure 4 provides algorithms to help select suitable agents to treat hepatitis B.

Recommendation 17: Standard IFN-alpha at a dose of $30 \mathrm{MIU} /$ week to $35 \mathrm{MIU} /$ week (5 MIU daily or $10 \mathrm{MIU}$ three times weekly) for 16 to 24 weeks can be used to treat $\mathrm{HBeAg}$-positive chronic hepatitis B (I).

Recommendation 18: PEG IFN-alpha-2a $180 \mu$ g given subcutaneously weekly for 24 to 48 weeks can be used to treat $\mathrm{HBeAg}$-positive chronic hepatitis B. PEG IFNalpha-2a for one year is suitable treatment for $\mathrm{HBeAg}$ negative chronic hepatitis B (I).

Recommendation 19: Lamivudine should be reserved for patients with a low viral load (not clearly defined, but probably less than $2 \times 10^{6} \mathrm{IU} / \mathrm{mL}$ ) (mostly $\mathrm{HBeAg}$ negative). If the serum HBV DNA concentration is greater than $60 \mathrm{IU} / \mathrm{mL}$ at six months of therapy, the therapeutic regimen should be changed. Alternatives include switching to entecavir or adding adefovir. The role of telbivudine in these circumstances is not clear (I).

Recommendation 20: Adefovir as primary therapy should be reserved for patients with a viral load less than approximately $2 \times 10^{6} \mathrm{IU} / \mathrm{mL}$ (mostly $\mathrm{HBeAg}$-negative). If the viral load has not fallen to below $200 \mathrm{IU} / \mathrm{mL}$ at the end of the first year of therapy, the treatment strategy should be changed. All pyrimidine analogues and tenofovir are suitable alternatives (I).

Recommendation 21: Entecavir is an effective first-line therapy for all patients regardless of viral load because it appears to be the most potent agent available and it is associated with very low rates of resistance (I).

Recommendation 22: Telbivudine is suitable for firstline use in all patients, including those with a high viral load (greater than 200,000 IU/mL). However, because of the risk of resistance, treatment efficacy should be assessed at six months (I). If the HBV DNA concentration is greather than $60 \mathrm{IU} / \mathrm{mL}$ at six months, the treatment strategy should be changed (II-2).

Recommendation 23: Following $\mathrm{HBe} \mathrm{Ag}$ seroconversion with nucleoside analogue treatment, a further six to 12 months of therapy is required (consolidation therapy) to maximize the durability of the response (II-2).

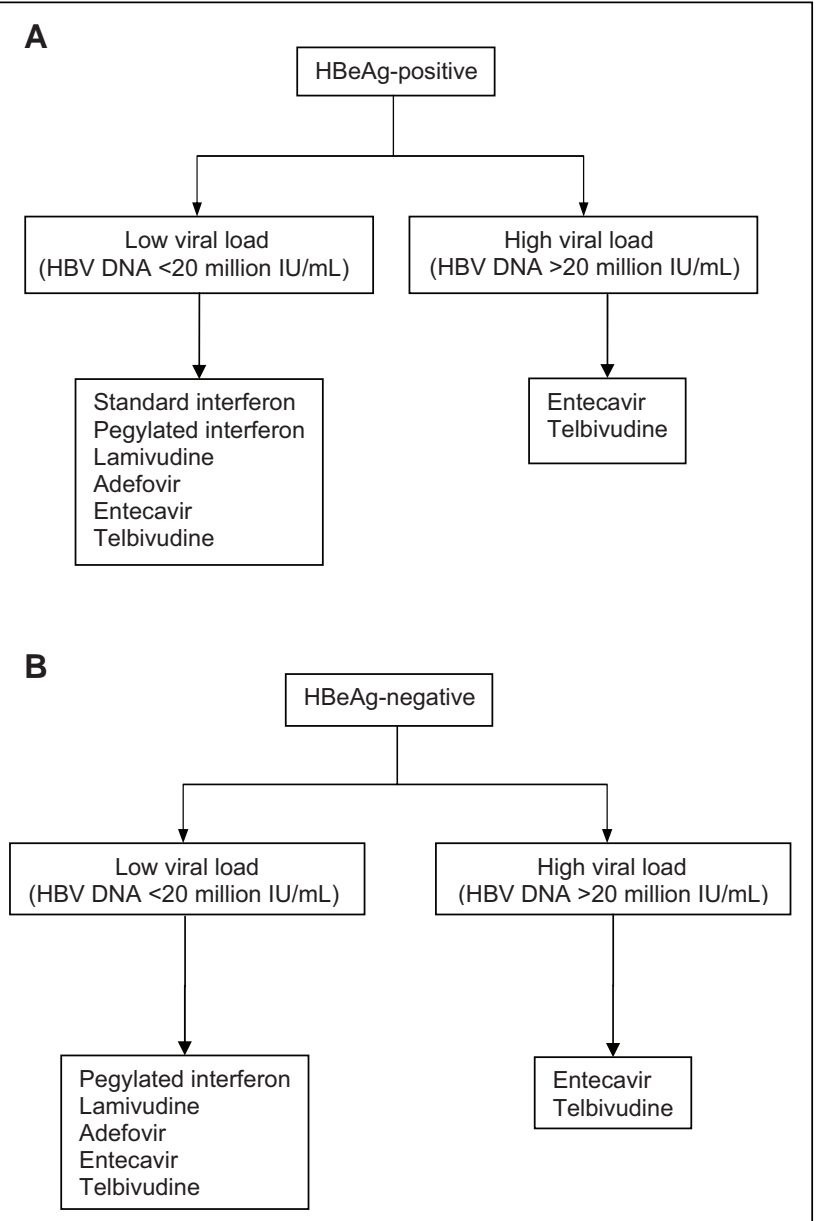

Figure 4) A Algorithm for the selection of specific agents for treatment of hepatitis $\mathrm{B}$ e antigen ( $\mathrm{HBeAg}$ )-positive patients with hepatitis $B$. B Algorithm for the selection of specific agents for treatment of $\mathrm{HBeAg}$ negative patients with hepatitis $B$. Response to adefovir, lamivudine and telbivudine should be assessed according to the text. HBV Hepatitis B virus

\section{On-treatment monitoring}

IFN therapy: Patients treated with IFNs need to be monitored closely. Liver tests and a complete blood count should be performed at monthly intervals. Thyroid-stimulating hormone should be measured every three months. When using PEG IFN for HBeAg-positive disease, HBV DNA concentration and $\mathrm{HBeAg} / \mathrm{anti}-\mathrm{HBe}$ can be measured after six months and at the end of treatment to determine response. These tests should also be performed every six months for 12 to 18 months after treatment withdrawal. A successful outcome is defined as antiHBe-positive with a normal ALT level for more than six months, with an HBV DNA concentration less than 20,000 IU/mL. Ideally, the HBV DNA concentration should be undetectable because the presence of detectable virus suggests a risk of disease relapse. $\mathrm{HBeAg}$-negative chronic hepatitis $\mathrm{B}$ patients treated with IFN should be monitored as for HBeAg-positive hepatitis, except that $\mathrm{HBeAg}$ and anti-HBe testing does not need to be repeated. Post-therapy, the HBV DNA concentration and ALT level should be monitored every three months.

Nucleoside analogues: Patients treated with nucleoside analogues should be monitored for HBV DNA concentration and ALT level initially at three and six months after starting treatment. This is to confirm an initial fall in viral load and, in the 


\section{TABLE 4}

\section{Definition of resistance to antiviral therapy}

\begin{tabular}{|c|c|}
\hline Primary treatment failure & $\begin{array}{l}\text { Less than } 2 \log _{10} \mathrm{IU} / \mathrm{mL} \text { decrease in viral load } \\
\text { measured at six months of treatment. This is } \\
\text { not antiviral resistance and is most commonly } \\
\text { related to lack of adherence with medication. }\end{array}$ \\
\hline Genotypic resistance & $\begin{array}{l}\text { Mutation of hepatitis B virus DNA polymerase is } \\
\text { known to decrease the efficacy of the antiviral } \\
\text { agent. }\end{array}$ \\
\hline Phenotypic resistance & $\begin{array}{l}\text { Defined by an in vitro assay demonstrating } \\
\text { decreased inhibition of viral replication in the } \\
\text { presence of the specific mutation in the } \\
\text { polymerase gene. }\end{array}$ \\
\hline Viral breakthrough & $\begin{array}{l}\text { Increase in viral load of } 1 \log _{10} \mathrm{IU} / \mathrm{mL} \text { or greater } \\
\text { above the nadir, measured on two consecutive } \\
\text { samples one month apart, occurring after the } \\
\text { first three months of therapy. This is commonly } \\
\text { due to genotypic resistance, but may also be } \\
\text { due to lack of adherence. }\end{array}$ \\
\hline $\begin{array}{l}\text { Clinical or biochemical } \\
\text { breakthrough }\end{array}$ & $\begin{array}{l}\text { A rise in alanine aminotransferase from its nadir } \\
\text { during treatment breakthrough associated with a } \\
\text { rise in viral load of } 1 \log _{10} \mathrm{IU} / \mathrm{mL} \text { or greater. This } \\
\text { may also be due to either genotypic resistance } \\
\text { or to lack of adherence. }\end{array}$ \\
\hline
\end{tabular}

case of lamivudine and telbivudine, to determine whether treatment with the same drug can be maintained, or whether another drug should be added or substituted (see above). Thereafter, patients on all nucleoside analogues should be monitored every three months to determine the lowest HBV DNA concentration that is achieved (nadir) and, subsequently, to allow for early detection of the development of viral breakthrough leading to resistance. Patients on adefovir also require that serum phosphate levels and renal function be monitored every three months. Patients on telbivudine require monitoring of creatine kinase.

Recommendation 24: The target HBV DNA

concentration on antiviral therapy is undetectable

virus. This should be measured using the most sensitive

test available (currently, the Taqman assay). Assays of

lower sensitivity are not recommended (III).

\section{Resistance to antiviral therapy}

$\mathrm{HBV}$ antiviral resistance testing: Mutations that confer resistance to antiviral agents occur spontaneously and are not caused by antiviral agents. Most resistant mutants have diminished replication competence and do not survive. However, in the presence of a selective pressure that inhibits the growth of wildtype virus, proliferation of some mutant virus species occurs until they become the dominant species. Depending on replication competence, the mutants can replicate at high levels over time. When a patient is on antiviral therapy, antiviral resistance may be suspected when serial HBV DNA testing shows increases in viral load of more than 10 -fold $\left(1 \log _{10} \mathrm{IU} / \mathrm{mL}\right)$ over nadir. Thus, monitoring for antiviral resistance requires regular assessment of HBV DNA concentrations. When resistance develops, particularly resistance to lamivudine, mutations in addition to the primary resistance mutation may occur that may lead to reduced susceptibility to other antivirals (99). Genotypic resistant virus

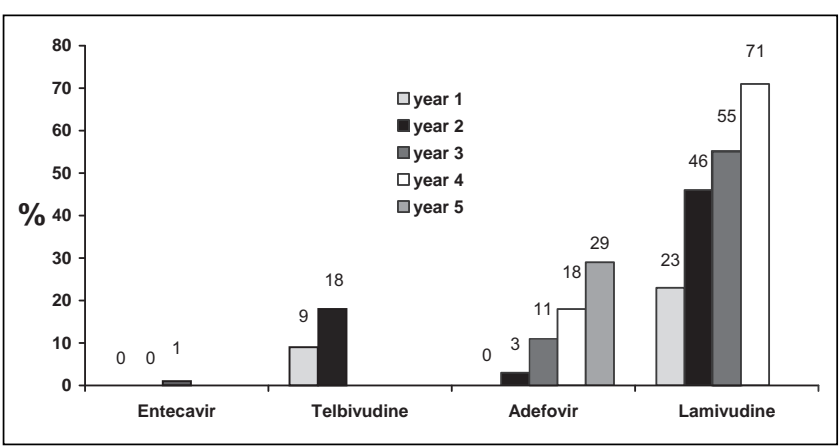

Figure 5) Rates of resistance to antiviral agents by duration of therapy. Data from references $76,80,84,88$ and 89

can be detected by various methods, such as direct genetic sequencing, reverse hybridization, restriction fragment analysis and other sequence-based detection. Sequencing requires that the mutant virus comprise at least $20 \%$ to $25 \%$ of the viral mixture. Reverse hybridization (INNO-LiPA; Immunogenetics, Belgium) may be able to detect lower frequency mixed infection (100). Because lamivudine resistance is associated with additional mutations other than the YMDD mutations, knowing the genetic mutations involved in resistance in any individual patient is essential to determine the most appropriate treatment for patients with lamivudine-resistant virus.

Recommendation 25: Clinicians must have access to genetic testing for mutant virus. This is used to differentiate between nonadherence and emergence of resistant virus. Viral breakthrough (defined later)

should be assessed by resistance testing before any new agents are introduced (III).

The development of resistance to antiviral therapy is not benign. There is considerable evidence that the benefits of viral suppression are lost $(101,102)$. Acute flares of hepatitis can occur, which can be life threatening in patients with cirrhosis. Therefore, the development of resistance to antivirals is a strong indication to change therapy. It is not acceptable for patients with lamivudine resistance, for example, to continue to be treated with lamivudine monotherapy when effective alternatives exist.

Definitions of nonresponse: All nucleoside analogues are associated with the development of viral resistance (Table 4). The rate at which antiviral resistance to individual nucleoside analogues develops has not been accurately defined because the long-term studies that have been used to determine these rates were not designed to quantify resistance. Furthermore, resistance was evaluated in subgroups of patients that were considerably smaller than the group initially recruited into the trials. Nonetheless, the studies have allowed some sense of the comparative rates at which each agent is subject to the development of resistance (103). These rates of resistance are shown in Figure 5.

Table 5 shows the substitutions in the viral polymerase gene that are associated with resistance to various agents (104). Table 6 shows the relative potency of the different antiviral agents in the face of some of the mutations known to confer resistance (104).

Resistance to antiviral therapy increases in frequency with increased baseline viral load, with failure of adequate suppression of virus and with viral genetic factors. Thus, the higher the viral load before treatment, the more likely that resistance will develop. The more slowly that viral load falls on therapy 


\section{TABLE 5}

Mutations conferring resistance to hepatitis $B$ nucleoside antivirals

\begin{tabular}{lcccc}
\hline Agent & Domain A & Domain B & Domain C & Domain D \\
\hline Lamivudine & L80V/I & V173L, L180M & M204V/I/S & \\
Adefovir & & A181V/T & & N236T \\
Entecavir & & I169T, T184G & S202I & M250V \\
Telbivudine & & M204I & \\
\hline
\end{tabular}

For each mutation, the number refers to the amino acid position, the letters before the numbers represent the wild-type amino acid and the letters after the number represent the substituted amino acid. ${ }^{*}$ The entecavir mutations only confer resistance in the presence of the M204V, M204I and L180M mutations; in the absence of these additional mutations, the entecavir mutations do not cause resistance

and the higher the nadir of the viral load, the more likely that resistance will occur.

It is important to detect resistance early, before the viral load rebounds fully and before the ALT level rises. Treatment is more likely to be effective if a new agent is introduced when the viral load is low than when it is high. To ensure that viral breakthrough is detected early, HBV DNA concentration should be measured every three months. Virological testing should be performed to confirm that viral breakthrough is due to resistance rather than to poor adherence. Treatment should be modified as soon as resistance is identified because, again, it is easier to treat when the viral load is low than when it is high.

Recommendation 26: HBV DNA should be monitored every three months to allow early detection of viral resistance at a stage when the viral load is still low (II-2).

Recommendation 27: Resistance genotyping should be performed in all patients in whom a viral rebound is detected to determine whether this is due to resistance or to poor adherence (II-2).

Management of primary nonresponse: Primary nonresponse (Table 4) should be investigated by resistance genotyping. If resistance mutations are not present, the most likely explanation for the lack of response is poor adherence. Occasionally there may be problems with absorption, or other pharmacological reasons for nonresponse, but these are poorly defined and cannot be tested for.

Management of resistance to specific antivirals:

Lamivudine resistance: Recent studies $(105,106)$ have shown that addition of adefovir after viral breakthrough, but before clinical breakthrough (ie, when the viral load is still low), is the preferred treatment (105). Under these circumstances, control of viral replication is almost invariably effective, and the rates of resistance to adefovir are very low. Switching to adefovir is associated with higher rates of adefovir resistance and is not recommended $(106,107)$. Entecavir is not a good choice for lamivudine resistance because the response to entecavir is blunted. Furthermore, resistance to entecavir occurs only in the setting of the mutations associated with lamivudine resistance and is $32 \%$ after three years (84). Virus that is resistant to lamivudine has a high likelihood of also being resistant to telbivudine. Tenofovir is effective in suppressing lamivudine-resistant hepatitis B, but whether tenofovir should be added or simply substituted for lamivudine has not been addressed.

Recommendation 28: The treatment of choice for lamivudine-resistant infection is the addition of adefovir (I).
TABLE 6

Relative activity of hepatitis $B$ antivirals in the presence of pre-existing mutations in the polymerase gene

\begin{tabular}{llll}
\hline & \multicolumn{3}{c}{ Resistance mutation } \\
\cline { 2 - 4 } & \multicolumn{1}{c}{ LAM resistant } & ADV resistant & ADV resistant \\
\cline { 2 - 4 } & E180M + M204V, & N236T & A181V \\
\hline $\begin{array}{l}\text { Mutation confers } \\
\text { reduced sensitivity to } \\
\text { to listed drugs }\end{array}$ & Telbivudine & Tenofovir & Lamivudine \\
Drugs remaining active & Adefovir & Lamivudine & Tenofovir \\
& Tenofovir & Entecavir & Entecavir \\
& & Telbivudine & \\
\hline
\end{tabular}

ADV Adefovir dipivoxil; LAM Lamivudine

Resistance to adefovir monotherapy: Genotypic resistance to adefovir monotherapy occurs in approximately 29\% of patients after five years (80). Clinical breakthrough occurs in approximately $11 \%(80)$. Lamivudine, tenofovir, telbivudine or entecavir can all be used. There are no large-scale trials confirming the efficacy of these agents, but in vitro data support these substitutions.

Resistance (or inadequate response) to combination lamivudine/adefovir in lamivudine-resistant patients: Evidence suggests that adequate suppression can be obtained with tenofovir $(91,108,109)$. Whether tenofovir should be added to lamivudine or simply substituted for adefovir has not been addressed.

Entecavir: Entecavir resistance requires the pre-existence of YMDD mutations. The presence of YMDD mutations decreases entecavir potency somewhat, but not enough to produce resistance. Nonetheless, in the presence of specific YMDD mutations (M204V and L180M), one or more additional mutations (I169T, T184G, S202I or M250V) do confer resistance (110). However, in the absence of the M204V and L180M mutations, these additional mutations are not associated with any decrease in potency. In the registration studies (82) of entecavir in lamivudine-resistant patients, entecavir-resistant mutations were detected in a proportion of patients before the introduction of entecavir. As a result, genotypic resistance was identified in $7 \%$ and viral breakthrough in $1.6 \%$ at the end of the first year of therapy (82). This rose to more than $30 \%$ at the end of the third year of therapy (84). In contrast, in nucleosidenaïve subjects, the rate of resistance to entecavir after three years was less than $1 \%(84)$.

Entecavir resistance can be treated with either adefovir or tenofovir (based on in vitro data only).

Telbivudine: Little is known about treatment of resistance to telbivudine, which occurs in $18 \%$ of patients at the end of two years of therapy (94). Resistance is mainly mediated by the M204I mutation and uncommonly by other mutations at the YMDD locus. Therefore, cross-resistance with lamivudine and emtricitabine can be expected. However, theoretically, adefovir and tenofovir could be used for telbivudine resistance. It is not clear whether entecavir can be used.

Other agents: Tenofovir has been shown to be an effective hepatitis B antiviral. Although it is not recommended for first-line use (because it is not yet licensed for this purpose), it is recommended for inadequate response to adefovir or adefovir resistance in patients with prior lamivudine resistance. Resistance to tenofovir has rarely been described in patients with hepatitis B, but studies are small and follow-up is short, and thus, the true resistance rate is not known. 


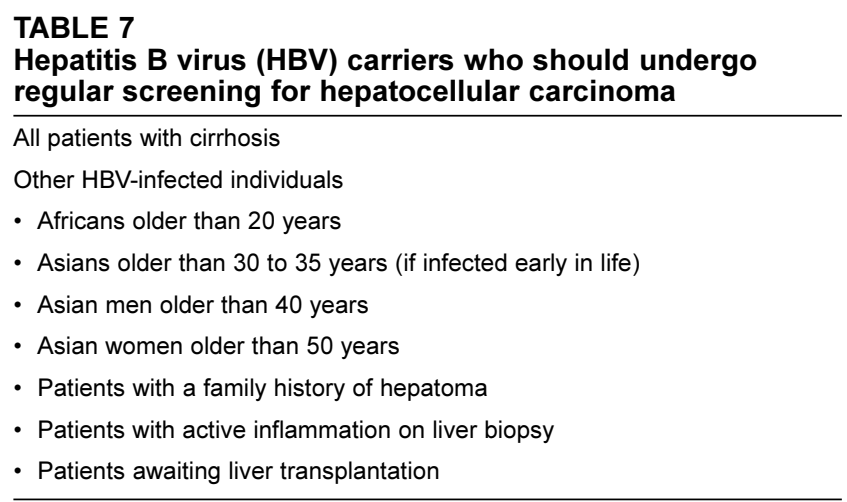

Post-treatment and long-term off-treatment monitoring Patients in whom treatment has not been offered still need continued follow-up, regardless of the status of their disease. Patients who have active viral replication are at risk for exacerbation of their hepatitis at any time. These flares may be shortlived, although cumulatively over time they may be very damaging. Because the period of ALT level elevation may be brief, frequent testing is necessary. Patients who are at risk for the development of flares should be monitored at least every three months, if not more often. Monitoring should include HBV DNA, ALT, tests of liver function and complete blood count. In HBeAg-negative patients who have low levels of viral replication (less than $2 \times 10^{3} \mathrm{IU} / \mathrm{mL}$ ) and are stable over one to two years, the frequency of monitoring can be reduced to initially every six months and eventually yearly. However, monitoring should still include HBV DNA, ALT and tests of liver function. Hepatoma screening: The annual incidence of hepatoma in HBV-infected individuals without cirrhosis is $0.4 \%$ to $0.6 \%$ in Asians (26), $0.2 \%$ in Alaskan natives (111) and approximately $0.3 \%$ in Caucasians (112). There are insufficient data on the incidence of HCC in Africans or North American Blacks. In cirrhosis, the incidence is greater than $2 \%$ per year, with a cumulative five-year incidence between $15 \%$ and $20 \%(113,114)$.

Surveillance should be performed every six months using abdominal ultrasound in those deemed to be at high risk for hepatoma (115). Alpha-fetoprotein testing is not an effective screening method (116). Not all patients with hepatitis B are at equal risk of developing HCC. Patients who should be screened for HCC are shown in Table 7.

\section{Management of hepatitis B cirrhosis}

All patients with well-compensated cirrhosis should be considered for therapy if the HBV DNA concentration is above $2000 \mathrm{IU} / \mathrm{mL}$ whether they are $\mathrm{HBeAg}$-positive or $\mathrm{HBeAg}$ negative. A suggested algorithm is shown in Figure 6. If the HBV DNA concentration is lower than $2000 \mathrm{IU} / \mathrm{mL}$, patients may be observed closely with measurements of HBV DNA and ALT every three to six months, or they may be considered for therapy. Standard or PEG IFN may be used with caution in these patients, but nucleos $(\mathrm{t})$ ide analogues are preferred. Nucleoside analogue treatment should continue indefinitely in patients with cirrhosis, even if such patients undergo $\mathrm{HBeAg}$ seroconversion.

\section{Hepatic decompensation}

All patients with hepatic decompensation due to hepatitis B should be treated with nucleoside analogues, regardless of

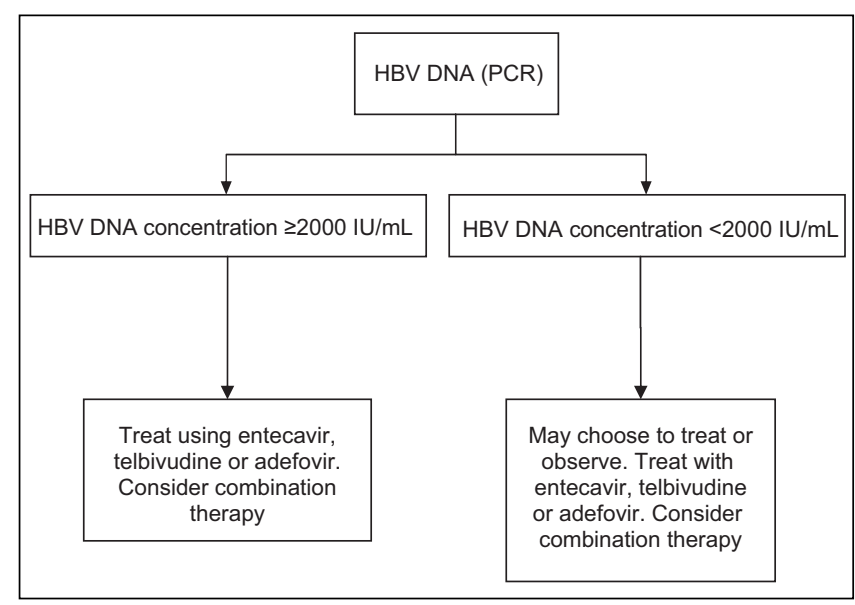

Figure 6) Suggested algorithm for management of patients with hepatitis B virus (HBV) cirrhosis. PCR Polymerase chain reaction

HBV DNA concentration, to either suppress viral replication or prevent possible flares in disease activity. Such patients should be considered for liver transplantation, and selection of the appropriate HBV therapy should be made in consultation with the local liver transplant program. Lamivudine and adefovir have been shown to improve hepatic function in such patients and may stave off the need for liver transplantation (117-119). However, because the development of resistant mutants can be associated with flares of hepatitis and hepatic decompensation (102), it is preferable to use drugs (entecavir or tenofovir) with the lowest rates of resistance. Combination of adefovir and lamivudine remains an option. Another alternative is the combination of tenofovir and emtricitabine, which is available as a single tablet for daily use. The renal function must be monitored carefully if tenofovir or adefovir are used in patients with cirrhosis because these patients are prone to renal dysfunction. Entecavir has not been fully evaluated for use in this situation, but, barring unexpected toxicity, it should also be an effective agent.

\section{Management of hepatitis B-HIV coinfection}

The prevalence of HBV coinfection in HIV-infected patients is approximately $10 \%(120)$. HIV coinfection tends to accelerate the natural history of HBV, and coinfected patients tend to have more histologically advanced disease and higher rates of liver-related mortality (121-123). All HIV-positive individuals should be screened for HBsAg and anti-HBs, and, if negative, they should be vaccinated (three double doses is recommended for such immunosuppressed individuals) (unpublished data). The treatment of the coinfected individual is complex, and ideally these patients should be managed using a multidisciplinary approach by specialists with an understanding of both infectious disease and liver disease. An understanding of the activity of various nucleoside analogues against both viruses, the potential for hepatotoxicity with certain HIV medications and issues regarding timing of HIV therapy is required.

IFN has only weak activity against HIV. Adefovir at the $10 \mathrm{mg}$ dose has limited activity against HIV. Adefovir use results in effective HBV suppression in lamivudine-resistant HBV in coinfected individuals $(124,125)$. There is in vitro cross-resistance between adefovir and tenofovir for the HIV DNA polymerase. Entecavir is believed not to be active against HIV. However, 
recent data hint that use of entecavir leads to selection of HIV polymerase mutants resistant to lamivudine and emtricitabine (unpublished data). In a placebo-controlled trial (126), 24 weeks of entecavir use was shown to result in a $-3.66 \log$ drop in HBV DNA in coinfected patients. Until the role of cross-resistance between HIV and HBV is better defined for these agents, neither adefovir nor entecavir is recommended for use as monotherapy against hepatitis B in HIV-positive individuals.

Lamivudine, tenofovir and emtricitabine all have activity against both HIV and HBV. Lamivudine is associated with higher rates of HBV resistance in coinfected individuals (90\% after four years) (127) and should never be used as monotherapy for HBV infection in untreated HIV patients because it may lead to HIV resistance to future therapies, including emtricitabine. Tenofovir is a potent suppressor of HBV DNA replication in both $\mathrm{HBeAg}$-positive and $\mathrm{HBeAg}$-negative coinfected patients (128). In a small study (92) in HIV-infected subjects with lamivudine-resistant $\mathrm{HBV}$, tenofovir was superior to adefovir in achieving HBV DNA negativity (100\% versus 44\% after 48 weeks of therapy). Furthermore, the vast majority of patients with lamivudine-resistant HBV who have incomplete viral suppression on adefovir can achieve HBV DNA negativity by switching to tenofovir (91).

HAART regimens containing tenofovir and lamivudine or emtricitabine in combination with the non-nucleoside reverse transcriptase inhibitors or protease inhibitors are ideal because these regimens have virological activity against both HIV and $\mathrm{HBV}$, and they infrequently cause hepatotoxicity. Therapy may not be needed for HIV in early stages of the disease. If therapy is required against both viruses, a combination of tenofovir and lamivudine or emtricitabine is recommended upfront to avoid the development of resistance. Tenofovir is the preferred drug in patients with HBV resistance to lamivudine. Immune reconstitution syndrome in advanced HIV therapy may occur after initiating HAART, and could result in a flare of hepatitis.

Recommendation 29: The need for hepatitis B therapy in HIV-positive patients remains an indication for the use of HAART (III).

Recommendation 30: Lamivudine should not be used as monotherapy for hepatitis B in HIV-positive patients (II-2).

Recommendation 31: Hepatitis B antivirals cannot yet be recommended as monotherapy for hepatitis B in HIV-infected patients (III).

\section{Management of $\mathrm{HBV}-\mathrm{HCV}$ coinfection}

In patients infected with both $\mathrm{HBV}$ and $\mathrm{HCV}$, only one of the two diseases is usually active (129). Such patients should have both HBV DNA and HCV RNA measurements performed. Subjects with high concentrations of HBV DNA but negative HCV RNA should be treated as any other HBV-infected patient. If the HBV DNA concentration is low (less than 20,000 IU/mL) and the HCV RNA is positive, the patient should be treated as any other patient with chronic HCV infection. A study (130) suggested that their response to IFN and ribavirin is similar to patients who are not coinfected. In patients treated for hepatitis C, HBV DNA concentrations should be monitored on therapy. If HBV DNA concentrations are greater than $2000 \mathrm{IU} / \mathrm{mL}$ and do not decrease with PEG IFN and ribavirin therapy, consideration should be given to adding a nucleoside analogue, such as entecavir, adefovir or lamivudine.

\section{Management of hepatitis B before pregnancy}

Decisions on antiviral therapy in young women must take into account the woman's desire for a family. Women planning a family should be treated with drugs that are safe in pregnancy. Lamivudine, adefovir and entecavir are category $\mathrm{C}$ drugs (ie, mutagenic in in vitro assays), and tenofovir and telbivudine are category B drugs (no mutagenicity). Although lamivudine is a category $\mathrm{C}$ drug, it has a record of safety in pregnancy. Tenofovir is also considered safe in pregnancy, although the experience with this drug is not as extensive as with lamivudine. As with other young patients, not all patients with high viral loads and elevated ALT levels need treatment, and it may be reasonable to temporarily withhold treatment in these patients. If withholding treatment is being contemplated, a biopsy is advised to confirm that the liver disease is mild. Close monitoring during pregnancy is necessary if the patient is not treated.

Although telbivudine is a category B drug, there is no experience with its use in pregnancy.

\section{Management of hepatitis B during pregnancy}

All pregnant mothers should be screened for HBsAg, and those who test positive should have their HBV DNA concentration measured because women with high concentrations of HBV DNA are at greater risk for transmission of virus to their offspring. Babies born to $\mathrm{HBs} \mathrm{Ag}$-positive mothers must receive passive and active immunization after birth. In general, this strategy is approximately greater than 95\% effective (131). In an American study (131) of approximately 800 children born to HBsAg-positive pregnant women between 1992 and 1997, $97 \%$ had anti-HBs $10 \mathrm{MIU} / \mathrm{mL}$ or greater, and only $2.2 \%$ became HBsAg-positive.

An uncontrolled study (132) from the Netherlands found that pregnant women with high HBV DNA concentrations (greater than $10^{9} \mathrm{IU} / \mathrm{mL}$ ) had rates of vertical transmission of $28 \%$ despite neonatal vaccination. This was reduced to $13 \%$ in eight pregnant women treated with lamivudine $150 \mathrm{mg}$ daily in the third trimester of pregnancy (132). In a randomized controlled trial (133) from China of lamivudine $100 \mathrm{mg}$ daily or placebo introduced at week $32 \pm 2$ weeks of gestation and continued postpartum for one month, there was a reduction of failure of neonatal active and passive vaccination in the lamivudine-treated group (18\% versus 39\% HBsAg-positive children at one year). To date, there appears to be no increased risk of fetal injuries due to lamivudine (134). The low risk of mother-to-infant transmission of hepatitis B in the presence of neonatal vaccination does not support the routine use of nucleoside analogues during the third trimester of pregnancy to reduce the risk of vertical transmission. However, pregnant women with high concentrations of HBV DNA should be referred to specialists for consideration of this treatment.

\section{Hepatitis B and renal failure}

HBV infection is associated with an increased risk of renal disease, including membranous nephropathy and glomerulonephritis, as well as other immune complex-associated diseases, such as polyarteritis nodosa (135). Suppression of HBV DNA can result in improved renal function in these patients. There is evidence that patients with HBV-related renal disease may have increased rates of responsiveness to IFN therapy (136). There are case reports of improvement of renal function with lamivudine in patients with hepatitis B-induced renal disease (137). Adefovir should be used with caution in 
this population because the drug itself may be associated with renal dysfunction. There is no experience reported with entecavir in patients with HBV-associated renal failure. All antiviral agents are excreted by the kidneys, and dose adjustments are required in renal failure.

\section{Chemotherapy and immunosuppression in HBV-infected patients}

All patients undergoing chemotherapy, bone marrow or solid organ transplantation, and some forms of monoclonal antibody therapy (eg, rituximab and infliximab) should be screened for HBV markers before treatment. Approximately 30\% to 50\% of HBV-negative individuals can experience reactivation of viral replication in association with increased ALT levels on immunosuppression (138). The only agent that has been studied during immunosuppression is lamivudine (139). However, any antiviral is likely to be effective if the viral load is initially low. Patients who start off with high viral loads may need more potent antivirals if resistance is to be avoided. Lamivudine (or more potent agents, if required) should be started pre-emptively in HBsAg-positive patients at least a few days before immunosuppressive therapy or chemotherapy is begun (140). There is no information to guide how long to treat such patients, but it would be reasonable to treat them for an additional three to six months after discontinuing immunosuppressive therapy or chemotherapy. Resistance is less of a concern because treatment is usually short term in these patients; therefore, lamivudine may be considered the first-line therapy (unless the initial viral load is very high). However, if long-term immunosuppressive therapy is required, consideration should be given to using entecavir or adefovir.

Whether subjects with markers of past HBV infection (HBsAg-negative but anti-hepatitis B core antigen [anti-HBc]positive) should also be treated prophylactically is unclear. Although the risk of reactivation may be low (less than 5\%) in such patients, re-emergence of HBV may be severe and even fatal in some of these patients. If patients are anti-HBs-negative, attempts should be made to improve immunity with a booster dose of the HBV vaccine. If nucleoside analogues are not used prophylactically in anti-HBc-positive patients, these individuals should be monitored regularly with ALT and HBsAg testing every one to three months, and antiviral therapy should be initiated as soon as there is evidence of HBV reactivation, without waiting for a rise in ALT levels.

All patients awaiting solid organ transplantation should be vaccinated against $\mathrm{HBV}$, although the likelihood of an effective antibody response is low (141). The risk of transmission of HBV is highest for liver recipients, and low for other solid organ transplants. Recipients of organs other than livers from antiHBc-positive anti-HBs-negative donors should receive lamivudine prophylaxis for at least the first post-transplant year, during which immunosuppression levels are at their highest. Recipients with documented seroconversion following hepatitis $B$ vaccination and persistent protective levels of anti-HBs (greater than $10 \mathrm{IU} / \mathrm{mL}$ ) do not require antiviral prophylaxis $(142,143)$. Prophylaxis against hepatitis B reactivation in patients undergoing liver transplantation are not discussed in the present paper because this is a highly specialized field and is limited to a small number of practitioners in the country.

Recommendation 32: All patients undergoing

chemotherapy (including chemoembolization); bone

marrow or solid organ transplantation; treatment with immunosuppressive monoclonal antibodies; or other immunosuppression should be screened for hepatitis B markers. Patients testing positive for HBsAg should receive antiviral prophylaxis before treatment, and should be monitored during and after therapy (I).

\section{Management of hepatitis B in children}

In highly endemic areas, early childhood infection, either vertical or horizontal, remains the predominant mode of transmission. In Canada, immigration and adoption of children from endemic regions account for most cases of HBV infection in children.

The age at acquisition of the virus influences the natural history of the HBV infection. Neonates, infants and young children develop chronic disease in approximately $90 \%$ of cases. In children aged one to five years, the chronicity rate is approximately $50 \%$, in older children the rate is approximately $6 \%$ to $10 \%$, and in young adults the rate is less than $5 \%$. Cirrhosis and HCC are rare in children, and when they do occur, they usually occur in older children. However, cases in young children are also well described. The spontaneous HBeAg seroconversion rate in children is high, and therefore treatment may not be necessary (144-148).

HBeAg-positive adolescents with elevated ALT should be observed for at least six to 12 months to determine whether they will spontaneously undergo $\mathrm{HBeAg}$ seroconversion. Those who continue to have high HBV DNA concentrations and fail to spontaneously undergo seroconversion can be considered for therapy, especially if the liver biopsy shows significant inflammation or fibrosis.

Children who have elevated ALT or evidence of active disease on liver biopsy may be candidates for therapy (149). There are data, however, that suggest that treatment-induced seroconversion in children merely advances spontaneous seroconversion by a few years (148). This may not be a worthwhile treatment goal. The long-term impact of IFN therapy in children remains unknown $(150,151)$. Only standard IFN and lamivudine have been assessed in children. IFN-alpha $6 \mathrm{MIU} / \mathrm{m}^{2}$ subcutaneously (maximum $10 \mathrm{MIU}$ ) three times per week for 24 weeks has been approved for children with HBeAg-positive disease, based on a study (152) that found greater HBeAg loss and HBV DNA negativity in IFN-treated children compared with control subjects $(26 \%$ versus $11 \%, \mathrm{P}<0.05)$. In addition to the usual side effects, IFN may interfere with growth in young children, although the effect may be transient. IFN should not be used in children younger than three years because of a risk of neurotoxicity. Lamivudine $3 \mathrm{mg} / \mathrm{kg} / \mathrm{day}$ (maximum $100 \mathrm{mg}$ ) for one year is also approved. However, as with adult disease, lamivudine resistance developed in 19\% of children after one year (153). A follow-up to this study (154) showed the durability of virological response to be $89 \%$ two years after stopping therapy. Although an additional two years of lamivudine use increased the virological response rates, the YMDD mutation rate increased to $64 \%$ after three years of therapy. Thus, lamivudine may not be suitable for use in young children because this is a group of patients with high viral loads, and many of these patients will require many years of therapy or may require treatment later after a period of inactive disease, after which the presence of lamivudine resistance will severely limit treatment choices.

Regardless of type of therapy, all children should continue to be followed at one- to two-year intervals to monitor for durability of response. 


\section{HBV-infected medical professionals}

Many jurisdictions have developed guidelines that restrict the practice of physicians, dentists and other health care professional because of $\mathrm{HBV}$ infection. The authors do not intend to revisit those restrictions or the issue of disclosure to patients. However, HBV-infected health professionals may choose to take treatment to reduce viral load and thereby preserve their careers. There is no clear-cut concentration of HBV DNA below which infection cannot occur, although the lowest viral concentration associated with documented transmission was 4000 copies/mL (approximately $800 \mathrm{IU} / \mathrm{mL}$ ) (155). In Europe, the consensus was that if the HBV DNA was below $2000 \mathrm{IU} / \mathrm{mL}$, the transmission risk was sufficiently low to permit exposure-prone procedures (155). In the United Kingdom, if the HBV DNA concentration is below $200 \mathrm{IU} / \mathrm{mL}$, surgeons can continue to operate. It is recommended that if such a course of action is undertaken, the lower the viral load in serum, the better, and a viral load undetectable by Taqman PCR should be the goal.

\section{CHRONIC HEPATITIS D}

$\mathrm{HDV}$ is a defective RNA virus that requires $\mathrm{HBs} A g$ for entry into and exit from the hepatocyte. Therefore, HDV may be acquired as a coinfection simultaneously with HBV or as a superinfection in a patient who is already a carrier of HBV. Infection with HDV usually causes an aggressive hepatitis and is associated with a higher risk of cirrhosis than HBV monoinfection. Although there are no seroprevalence data, the prevalence of HDV infection in Canada is thought to be low. Those at highest risk for HDV infection are HBsAg carriers who acquired their infection through injection drug use and immigrants from countries where HDV is endemic (such as Italy, Russia, Romania, Spain, Turkey and Egypt). Patients with these risk factors, particularly in the setting of a high ALT level, with undetectable HBV DNA should be tested for HDV antibody. If the HDV antibody is positive, active infection should ideally be confirmed with an HDV RNA measurement, and treatment should be considered in those with active infection. Unfortunately, the HDV RNA assay is not commercially available, and homegrown assays are not standardized. Patients with active hepatitis D should be treated in expert centres.

Unfortunately, there are limited data to guide the treatment of HDV. Lamivudine and ribavirin appear to have no role in the management of HDV. Several small studies (156-158) suggest that standard IFN and PEG IFN result in sustained virological response rates between $17 \%$ and $43 \%$, with the highest response rates seen in those treated with prolonged PEG IFN. If possible, treatment response should be monitored with an HDV RNA measurement at month 6, and in those who fail to achieve at least a $3 \log$ drop, therapy should be discontinued. Alternatively, in the absence of HDV RNA monitoring, normalization of the ALT level suggests suppression of virus.

Recommendation 33: Hepatitis D should be treated with PEG IFN monotherapy at standard doses for a minimum of 12 months (II-2).

ACKNOWLEDGEMENTS: The authors would like to acknowledge the following speakers, without whose expertise the preparation of this document would not have been possible. The following speakers gave freely of their time and contributed immensely to the development of the guidelines: Gerry Minuk, University of Manitoba; Bernard Duval, Laval University; Andrew Mason, University of Alberta; Mel Krajden, British Columbia Centers for Disease Control; Sam Lee, University of Calgary; Scott Fung, University of Toronto; Vincent Bain, University of Alberta; Jenny Heathcote, University of Toronto; Mark Swain, University of Calgary; Jean-Pierre Villeneuve, University of Montreal; Bernard Willems, University of Montreal; Gary Garber, University of Ottawa; Richard Schreiber, University of British Columbia; and Kevork Peltekian, Dalhousie University.

\section{REFERENCES}

1. Remis R (personal communication). Estimating the Number of Persons Infected with Hepatitis C in Canada. Submitted to Health Canada, 2005.

2. Sherman M, Bain V, Villeneuve JP, et al. The management of chronic viral hepatitis: A Canadian consensus conference 2004. Can J Gastroenterol 2004;18:715-28.

3. Lok AS, McMahon BJ. Chronic hepatitis B. Hepatology 2007:45:507-39.

4. de Franchis R, Hadengue A, Lau G, et al; EASL Jury. EASL International Consensus Conference on Hepatitis B. 13-14 September, 2002, Geneva, Switzerland. Consensus statement (long version). J Hepatol 2003;39(Suppl 1):S3-25.

5. Liaw YF, Leung N, Guan R, et al; Asian-Pacific consensus update working party on chronic hepatitis B. Asian-Pacific consensus statement on the management of chronic hepatitis B. Asian-Pacific consensus statement on the management of chronic hepatitis B: A 2005 update. Liver Int 2005;25:472-89.

6. Prati D, Taioli E, Zanella A, et al. Updated definitions of healthy ranges for serum alanine aminotransferase levels. Ann Intern Med 2002;137:1-10.

7. Kim HC, Nam CM, Jee SH, Han KH, Oh DK, Suh I. Normal serum aminotransferase concentration and risk of mortality from liver diseases: Prospective cohort study. BMJ 2004;328:983.

8. Yuen MF, Yuan HJ, Wong DK, et al. Prognostic determinants for chronic hepatitis B in Asians: Therapeutic implications. Gut 2005;54:1610-4

9. Yang HI, Lu SN, Liaw YF, et al; Taiwan Community-Based Cancer Screening Project Group. Hepatitis B e antigen and the risk of hepatocellular carcinoma. N Engl J Med 2002;347:168-74

10. Lai M, Hyatt B, Afdhal N. Role of liver biopsy in patients with normal ALT and high HBV DNA. Hepatology 2005;42:720A. (Abst)

11. Zeuzem S, Diago M, Gane E, et al; PEGASYS Study NR16071 Investigator Group. Peginterferon alfa-2a (40 kilodaltons) and ribavirin in patients with chronic hepatitis $\mathrm{C}$ and normal aminotransferase levels. Gastroenterology 2004;127:1724-32.

12. Decision Analysis on Screening for HBV in Immigrants. Statistics and Risk Assessment Section of the Blood Safety Surveillance and Health Care Acquired Infection Division, Population and Public Health Branch Health Canada, 2000

13. Centers for Disease Control and Prevention (CDC). Screening for chronic hepatitis B among Asian/Pacific Islander populations - New York City, 2005. MMWR Morb Mortal Wkly Rep 2006;55:505-9.

14. Gilca V, Duval B, Boulianne N, Dion R, De Serres G. Impact of the Quebec school-based hepatitis B immunization program and potential benefit of the addition of an infant immunization program. Pediatr Infect Dis J 2006;25:372-4.

15. Canadian Immunization Guide, 7th Edn. Ottawa: Public Health Agency of Canada, 2006:189-204.

16. Mast EE, Weinbaum CM, Fiore AE, et al; Advisory Committee on Immunization Practices (ACIP) Centers for Disease Control and Prevention (CDC). A comprehensive immunization strategy to eliminate transmission of hepatitis B virus infection in the United States: Recommendations of the Advisory Committee on Immunization Practices (ACIP) Part II: Immunization of adults. MMWR Recomm Rep 2006;55:1-33.

17. Villeneuve E, Vincelette J, Villeneuve JP. Ineffectiveness of hepatitis B vaccination in cirrhotic patients waiting for liver transplantation. Can Gastroenterol 2000;14(Suppl B):59B-62B.

18. Saldanha J, Gerlich W, Lelie N, Dawson P, Heermann K, Heath A; WHO Collaborative Study Group. An international collaborative study to establish a World Health Organization international standard for hepatitis B virus DNA nucleic acid amplification techniques. Vox Sang 2001;80:63-71.

19. Laperche S, Thibault V, Bouchardeau F, et al. Expertise of laboratories in viral load quantification, genotyping, and precore mutant determination for hepatitis B virus in a multicenter study. J Clin Microbiol 2006;44:3600-7.

20. Ronsin C, Pillet A, Bali C, Denoyel GA. Evaluation of the COBAS AmpliPrep-total nucleic acid isolation-COBAS TaqMan hepatitis B virus (HBV) quantitative test and comparison to the VERSANT HBV DNA 3.0 assay. J Clin Microbiol 2006;44:1390-9.

21. Pawlotsky JM, Bastie A, Hezode C, et al. Routine detection and quantification of hepatitis B virus DNA in clinical laboratories: Performance of three commercial assays. J Virol Methods 2000;85:11-21.

22. Norder H, Courouce AM, Coursaget P, et al. Genetic diversity of hepatitis B virus strains derived worldwide: Genotypes, subgenotypes, and $\mathrm{HBsAg}$ subtypes. Intervirology 2004;47:289-309. 
23. Miyakawa Y, Mizokami M. Classifying hepatitis B virus genotypes. Intervirology 2003;46:329-38.

24. Liu CJ, Kao JH, Chen DS. Therapeutic implications of hepatitis B virus genotypes. Liver Int 2005;25:1097-107.

25. Janssen HL, van Zonneveld M, Senturk H, et al. Pegylated interferon alfa-2b alone or in combination with lamivudine for HBeAg-positive chronic hepatitis B: A randomised trial. Lancet 2005;365:123-9.

26. Beasley RO, Hwang LU. Epidemiology of hepatocellular carcinoma. In: Vyas GN, Dienstag JL, Hoofnagle JN, eds. Viral Hepatitis and Liver Disease. New York: Grune and Stratton, 1984:209-23.

27. Lee W. Hepatitis B virus infection. N Engl J Med 1997;337:1733-45.

28. Liaw YF, Chu CM, Huang MJ, Sheen IS, Yang CY, Lin DY. Determinants for hepatitis B e antigen clearance in chronic type B hepatitis. Liver 1984;4:301-6.

29. Lok AS, Lai CL, Wu PC, Leung EK, Lam TS. Spontaneous hepatitis B e antigen to antibody seroconversion and reversion in Chinese patients with chronic hepatitis B virus infection. Gastroenterology 1987;92:1839-43.

30. Chu CM, Hung SJ, Lin J, Tai DI, Liaw YF. Natural history of hepatitis B e antigen to antibody seroconversion in patients with normal serum aminotransferase levels. Am J Med 2004;116:829-34.

31. Hadziyannis SJ, Vassilopoulos D. Hepatitis B e antigen-negative chronic hepatitis B. Hepatology 2001;34:617-24.

32. Yim HJ, Lok AS. Natural history of chronic hepatitis B virus infection: What we knew in 1981 and what we know in 2005. Hepatology 2006;43(2 Suppl 1):S173-81.

33. Chen G, Lin W, Shen F, Iloeje UH, London WT, Evans AA. Past HBV viral load as predictor of mortality and morbidity from HCC and chronic liver disease in a prospective study. Am J Gastroenterol 2006;101:1797-803.

34. Iloeje UH, Yang HI, Su J, Jen CL, You SL, Chen CJ; Risk Evaluation of Viral Load Elevation and Associated Liver Disease/Cancer-In HBV (the REVEAL-HBV) Study Group. Predicting cirrhosis risk based on the level of circulating hepatitis B viral load. Gastroenterology 2006;130:678-86.

35. Chen CJ, Yang HI, Su J, et al; REVEAL-HBV Study Group. Risk of hepatocellular carcinoma across a biological gradient of serum hepatitis B virus DNA level. JAMA 2006;295:65-73.

36. Yu MW, Yeh SH, Chen PJ, et al. Hepatitis B virus genotype and DNA level and hepatocellular carcinoma: A prospective study in men. J Natl Cancer Inst 2005;97:265-72

37. Liaw YF, Sollano JD. Factors influencing liver disease progression in chronic hepatitis B. Liver Int 2006;26(Suppl 2):23-9.

38. Fattovich G, Rugge M, Brollo L, et al. Clinical, virologic and histologic outcome following seroconversion from HBeAg to anti-HBe in chronic hepatitis type B. Hepatology 1986;6:167-72.

39. Lin X, Robinson NJ, Thursz M, et al. Chronic hepatitis B virus infection in the Asia-Pacific region and Africa: Review of disease progression. J Gastroenterol Hepatol 2005;20:833-43.

40. Liaw YF, Sheen IS, Chen TJ, Chu CM, Pao CC. Incidence, determinants and significance of delayed clearance of serum HBsAg in chronic hepatitis B virus infection: A prospective study. Hepatology 1991;13:627-31.

41. Yu MW, Hsu FC, Sheen IS, et al. Prospective study of hepatocellular carcinoma and liver cirrhosis in asymptomatic chronic hepatitis B virus carriers. Am J Epidemiol 1997;145:1039-47.

42. Park BK, Park YN, Ahn SH, et al. Long-term outcome of chronic hepatitis B based on histological grade and stage. J Gastroenterol Hepatol 2007;22:383-8.

43. Lok AS, Lai CL. A longitudinal follow-up of asymptomatic hepatitis B surface antigen-positive Chinese children. Hepatology 1988;8:1130-3.

44. Chang MH, Hsu HY, Hsu HC, Ni YH, Chen JS, Chen DS. The significance of spontaneous hepatitis B e antigen seroconversion in childhood: With special emphasis on the clearance of hepatitis B e antigen before 3 years of age. Hepatology 1995;22:1387-92

45. Brook MG, McDonald JA, Karayiannis P, et al. Randomised controlled trial of interferon alfa 2A (rbe) (Roferon-A) for the treatment of chronic hepatitis B virus (HBV) infection: Factors that influence response. Gut 1989;30:1116-22.

46. Brunetto MR, Oliveri F, Colombatto P, Coco B, Ciccorossi P, Bonino F. Treatment of HBeAg-negative chronic hepatitis B with interferon or pegylated interferon. J Hepatol 2003;39(Suppl 1):S164-7.

47. Craxi A, Di Bona D, Camma C. Interferon-alpha for HBeAg-positive chronic hepatitis B. J Hepatol 2003;39(Suppl 1):S99-105.

48. Perrillo RP, Schiff ER, Davis GL, et al. A randomized, controlled trial of interferon alfa- $2 \mathrm{~b}$ alone and after prednisone withdrawal for the treatment of chronic hepatitis B. The Hepatitis Interventional Therapy Group. N Engl J Med 1990;323:295-301.

49. Wong DK, Cheung AM, O'Rourke K, Naylor CD, Detsky AS, Heathcote J. Effect of alpha-interferon treatment in patients with hepatitis B e antigenpositive chronic hepatitis B. A meta-analysis. Ann Intern Med 1993;119:312-23.

50. Lau DT, Everhart J, Kleiner DE, et al. Long-term follow-up of patients with chronic hepatitis B treated with interferon alfa. Gastroenterology 1997;113:1660-7.

51. Lin SM, Sheen IS, Chien RN, Chu CM, Liaw YF. Long-term beneficial effect of interferon therapy in patients with chronic hepatitis B virus infection. Hepatology 1999;29:971-5.

52. Lok AS, Chung HT, Liu VW, Ma OC. Long-term follow-up of chronic hepatitis B patients treated with interferon alfa. Gastroenterology 1993; 105:1833-8.
53. Korenman J, Baker B, Waggoner J, Everhart JE, Di Bisceglie AM, Hoofnagle JH. Long-term remission of chronic hepatitis B after alphainterferon therapy. Ann Intern Med 1991;114:629-34.

54. Krogsgaard $\mathrm{K}$. The long-term effect of treatment with interferon-alpha 2a in chronic hepatitis B. The Long-Term Follow-up Investigator Group. The European Study Group on Viral Hepatitis (EUROHEP). Executive Team on Anti-Viral Treatment. J Viral Hepat 1998;5:389-97.

55. Cooksley WG, Piratvisuth T, Lee SD, et al. Peginterferon alpha-2a (40 kDa): An advance in the treatment of hepatitis B e antigen-positive chronic hepatitis B. J Viral Hepat 2003;10:298-305.

56. Lau GK, Piratvisuth T, Luo KX, et al. Peginterferon Alfa-2a, lamivudine, and the combination for $\mathrm{HBeAg}$-positive chronic hepatitis B. N Engl J Med 2005;352:2682-95

57. Niederau C, Heintges T, Lange $S$, et al. Long-term follow-up of HBeAgpositive patients treated with interferon alfa for chronic hepatitis $B$ N Engl J Med 1996;334:1422-7.

58. Fattovich G, Giustina G, Realdi G, Corrocher R, Schalm SW. Long-term outcome of hepatitis B e antigen-positive patients with compensated cirrhosis treated with interferon alfa. European Concerted Action on Viral Hepatitis (EUROHEP). Hepatology 1997;26:1338-42.

59. Lin SM, Yu ML, Lee CM, et al. Interferon therapy in HBeAg positive chronic hepatitis reduces progression to cirrhosis and hepatocellular carcinoma. J Hepatol 2007;46:45-52.

60. Marcellin P, Lau GK, Bonino F, et al; Peginterferon Alfa-2a HBeAg-Negative Chronic Hepatitis B Study Group. Peginterferon alfa-2a alone, lamivudine alone, and the two in combination in patients with $\mathrm{HBeAg-negative} \mathrm{chronic}$ hepatitis B. N Engl J Med 2004;351:1206-17.

61. Lai CL, Ching CK, Tung AK, et al. Lamivudine is effective in suppressing hepatitis B virus DNA in Chinese hepatitis B surface antigen carriers: A placebo-controlled trial. Hepatology 1997;25:241-4.

62. Lok AS, Lai CL, Leung N, et al. Long-term safety of lamivudine treatment in patients with chronic hepatitis B. Gastroenterology 2003;125:1714-22.

63. Lai CL, Dienstag J, Schiff E, et al. Prevalence and clinical correlates of YMDD variants during lamivudine therapy for patients with chronic hepatitis B. Clin Infect Dis 2003;36:687-96.

64. Lee YS, Suh DJ, Lim YS, et al. Increased risk of adefovir resistance in patients with lamivudine-resistant chronic hepatitis B after 48 weeks of adefovir dipivoxil monotherapy. Hepatology 2006;43:1385-91.

65. Liaw YF, Sung JJ, Chow WC, et al; Cirrhosis Asian Lamivudine Multicentre Study Group. Lamivudine for patients with chronic hepatitis B and advanced liver disease. N Engl J Med 2004;351:1521-31.

66. Di Marco V, Di Stefano R, Ferraro D, et al. HBV-DNA suppression and disease course in HBV cirrhosis patients on long-term lamivudine therapy. Antivir Ther 2005;10:431-9.

67. Mommeja-Marin H, Mondou E, Blum MR, Rousseau F. Serum HBV DNA as a marker of efficacy during therapy for chronic HBV infection: Analysis and review of the literature. Hepatology 2003;37:1309-19.

68. Suzuki F, Tsubota A, Arase Y, et al. Efficacy of lamivudine therapy and factors associated with emergence of resistance in chronic hepatitis B virus infection in Japan. Intervirology 2003;46:182-9.

69. Yuen MF, Sablon E, Hui CK, Yuan HJ, Decraemer H, Lai CL. Factor associated with hepatitis B virus DNA breakthrough in patients receiving prolonged lamivudine therapy. Hepatology 2001;34:785-91.

70. Lai CL, Chien RN, Leung NW, et al. A one-year trial of lamivudine for chronic hepatitis B. Asia Hepatitis Lamivudine Study Group. N Engl J Med 1998;339:61-8.

71. Dienstag JL, Schiff ER, Wright TL, et al. Lamivudine as initial treatment for chronic hepatitis B in the United States. N Engl J Med 1999;341:1256-63.

72. Schalm SW, Heathcote J, Cianciara J, et al. Lamivudine and alpha interferon combination treatment of patients with chronic hepatitis B infection: A randomised trial. Gut 2000;46:562-8.

73. Chang TT, Gish RG, de Man R, et al; BEHoLD AI463022 Study Group. A comparison of entecavir and lamivudine for HBeAg-positive chronic hepatitis B. N Engl J Med 2006;354:1001-10.

74. Dienstag JL, Cianciara J, Karayalcin S, et al. Durability of serologic response after lamivudine treatment of chronic hepatitis B. Hepatology 2003;37:748-55.

75. Song BC, Suh DJ, Lee HC, Chung YH, Lee YS. Hepatitis B e antigen seroconversion after lamivudine therapy is not durable in patients with chronic hepatitis B in Korea. Hepatology 2000;32:803-6.

76. Chang TT, Lai CL, Chien RN, et al. Four years of lamivudine treatment in Chinese patients with chronic hepatitis B. J Gastroenterol Hepatol 2004;19:1276-82.

77. Locarnini S, Qi X, Arterburn S, et al. Incidence and predictors of emergence of adefovir resistant HBV during four years of adefovir dipivoxil (ADV) therapy for patients with chronic hepatitis b (CHB). J Hepatol 2005;42(Suppl 2):17.

78. Marcellin P, Chang TT, Lim SG, et al; Adefovir Dipivoxil 437 Study Group. Adefovir dipivoxil for the treatment of hepatitis B e antigen-positive chronic hepatitis B. N Engl J Med 2003;348:808-16.

79. Chang TT, Shiffman ML, Tong M, et al. Durability of HBeAg seroconversion following adefovir dipivoxil treatment for chronic hepatitis B. J Hepatol 2006;44(Suppl 2):S187.

80. Hadziyannis SJ, Tassopoulos NC, Heathcote EJ, et al; Adefovir Dipivoxil 438 Study Group. Long-term therapy with adefovir dipivoxil for HBeAgnegative chronic hepatitis B for up to 5 years. Gastroenterology 2006;131:1743-51. 
81. Lai CL, Shouval D, Lok AS, et al; BEHoLD AI463027 Study Group. Entecavir versus lamivudine for patients with $\mathrm{HBeAg-negative} \mathrm{chronic}$ hepatitis B. N Engl J Med 2006;354:1011-20.

82. Sherman M, Yurdaydin C, Sollano J, et al; AI463026 BEHoLD Study Group. Entecavir for treatment of lamivudine-refractory, $\mathrm{HBeAg}$-positive chronic hepatitis B. Gastroenterology 2006;130:2039-49.

83. Colonno RJ, Rose R, Baldick CJ, et al. Entecavir resistance is rare in nucleoside naive patients with hepatitis B. Hepatology 2006;44:1656-65.

84. Colonno R, Rose RE, Pokornowski K, et al. Assessment at three years show high barrier to resistance is maintained in entecavir-treated nucleoside naïve patients while resistance emergence increases over time in lamivudine refractory patients. Hepatology 2006;44(Suppl 1):229A-30A. (Abst)

85. Tenney DJ, Rose RE, Baldick CJ, et al. Two-year assessment of entecavir resistance in Lamivudine-refractory hepatitis B virus patients reveals different clinical outcomes depending on the resistance substitutions present. Antimicrob Agents Chemother 2007;51:902-11.

86. Kanwal F, Farid M, Martin P, et al. Treatment alternatives for hepatitis B cirrhosis: A cost-effectiveness analysis. Am J Gastroenterol 2006;101:2076-89.

87. Chang TT, Chao YC, Kaymakoglu S, et al. Entecavir maintained virologic suppression through 3 years of treatment in antiviral-naïve $\mathrm{HBeAg}(+)$ patients (ETV 022/901). Hepatology 2006;44(Suppl 1):66A. (Abst)

88. Lai CL, Leung N, Teo EK, et al; Telbivudine Phase II Investigator Group. A 1-year trial of telbivudine, lamivudine, and the combination in patient with hepatitis B e antigen-positive chronic hepatitis B. Gastroenterology 2005;129:528-36.

89. Lai CL, Gane E, Hsu CW, et al; Globe Study Group. Two-year results from the globe trial in patients with hepatitis B: Greater clinical and antiviral efficacy for telbivudine (Ldt) vs. lamivudine Hepatology 2005;42(Suppl 1):748A. (Abst)

90. DiBisceglie A, Lai CL, Gane E, et al; Study Group The GLOBE. Telbivudine GLOBE trial: Maximal early HBV suppression is predictive of optimal twoyear efficacy in nucleoside-treated hepatitis B patients. Hepatology 2006;44(Suppl 1):230A. (Abst)

91. van Bommel F, Zollner B, Sarrazin C, et al. Tenofovir for patients with lamivudine-resistant hepatitis B virus (HBV) infection and high HBV DNA level during adefovir therapy. Hepatology 2006;44:318-25.

92. van Bommel F, Wunsche T, Mauss S, et al. Comparison of adefovir and tenofovir in the treatment of lamivudine-resistant hepatitis B virus infection. Hepatology 2004;40:1421-5.

93. Peters MG, Andersen J, Lynch P, et al; ACTG Protocol A5127 Team. Randomized controlled study of tenofovir and adefovir in chronic hepatitis B virus and HIV infection: ACTG A5127. Hepatology 2006;44:1110-6.

94. Sheldon J, Camino N, Rodes B, et al. Selection of hepatitis B virus polymerase mutations in HIV-coinfected patients treated with tenofovir. Antivir Ther 2005;10:727-34.

95. Lim SG, Ng TM, Kung N, et al; Emtricitabine FTCB-301 Study Group. A double-blind placebo-controlled study of emtricitabine in chronic hepatitis B. Arch Intern Med 2006;166:49-56.

96. Gish RG, Trinh H, Leung N, et al. Safety and antiviral activity of emtricitabine (FTC) for the treatment of chronic hepatitis B infection: A two-year study. J Hepatol 2005;43:60-6.

97. Peters MG, Hann Hw H, Martin P, et al. Adefovir dipivoxil alone or in combination with lamivudine in patients with lamivudine-resistant chronic hepatitis B. Gastroenterology 2004;126:91-101.

98. Lai CL, Leung N, Teo EK, et al; Telbivudine Phase II Investigator Group. A 1-year trial of telbivudine, lamivudine, and the combination in patients with hepatitis B e antigen-positive chronic hepatitis B. Gastroenterology 2005; 129:528-36

99. Lee YS, Suh DJ, Lim YS, et al. Increased risk of adefovir resistance in patients with lamivudine-resistant chronic hepatitis B after 48 weeks of adefovir dipivoxil monotherapy. Hepatology 2006:43:1385-91.

100. Lok AS, Zoulim F, Locarnini S, et al. Monitoring drug resistance in chronic hepatitis B virus (HBV)-infected patients during lamivudine therapy: Evaluation of performance of INNO-LiPA HBV DR assay. J Clin Microbiol 2002;40:3729-34

101. Wang JH, Lu SN, Lee CM, Lee JF, Chou YP. Fatal hepatic failure after emergence of the hepatitis B virus mutant during lamivudine therapy in a patient with liver cirrhosis. Scand J Gastroenterol 2002;37:366-9.

102. Fung SK, Andreone P, Han SH, et al. Adefovir-resistant hepatitis B can be associated with viral rebound and hepatic decompensation. J Hepatol 2005;43:937-43

103. Dienstag JL, Wei LJ, Xu D, Kreter B. Cross-study analysis of the relative efficacie of oral antiviral therapies for chronic hepatitis B infection in nucleoside-naive patients. Clin Drug Investig 2007;27:35-49.

104. Zoulim F. Mechanism of viral persistence and resistance to nucleoside and nucleotide analogs in chronic hepatitis B virus infection. Antiviral Res 2004;64:1-15

105. Lampertico P, Vigano M, Manenti E, Iavarone M, Lunghi G, Colombo M. Adefovir rapidly suppresses hepatitis B in $\mathrm{HBeAg}$-negative patients developing genotypic resistance to lamivudine. Hepatology 2005;42:1414-9.

106. Rapti I, Dimou E, Mitsoula P, Hadziyannis S. Adding-on versus switching-to adefovir therapy in lamivudine-resistant $\mathrm{HBeAg}$-negative chronic hepatitis B. Hepatology 2007:45:307-13.

107. Liaw YF, Lee CM, Chien RN, Yeh CT. Switching to adefovir monotherapy after emergence of lamivudine-resistant mutations in patients with liver cirrhosis. J Viral Hepat 2006;13:250-5.
108. Brunelle MN, Jacquard AC, Pichoud C, et al. Susceptibility to antivirals of a human HBV strain with mutations conferring resistance to both lamivudine and adefovir. Hepatology 2005;41:1391-8.

109. Villeneuve JP, Durantel D, Durantel S, et al. Selection of a hepatitis B virus strain resistant to adefovir in a liver transplantation patient. J Hepatol 2003;39:1085-9.

110. Tenney DJ, Levine SM, Rose RE, et al. Clinical emergence of entecavirresistant hepatitis $\mathrm{B}$ virus requires additional substitutions in virus already resistant to lamivudine. Antimicrob Agents Chemother 2004:48:3498-507.

111. McMahon BJ, Alberts SR, Wainwright RB, Bulkow L, Lanier AP. Hepatitis B related sequelae. Prospective study in 1400 hepatitis B surface antigenpositive Alaska native carriers. Arch Intern Med 1990;150:1051-4.

112. Realdi G, Fattovich G, Hadziyannis S, et al. Survival and prognostic factors in 366 patients with compensated cirrhosis type B: A multicenter study. The Investigators of the European Concerted Action on Viral Hepatitis (EUROHEP). J Hepatol 1994;21:656-66.

113. Degos F, Christidis C, Ganne-Carrie N, et al. Hepatitis C virus related cirrhosis: Time to occurrence of hepatocellular carcinoma and death. Gut 2000;47:131-6.

114. Chiaramonte M, Stroffolini T, Vian A, et al. Rate of incidence of hepatocellular carcinoma in patients with compensated viral cirrhosis. Cancer 1999;85:2132-7.

115. Bruix J, Sherman M; Practice Guidelines Committee, American Association for the Study of Liver Diseases. Management of hepatocellular carcinoma. Hepatology 2005;42:1208-36

116. Trevisani F, D'Intino PE, Morselli-Labate AM, et al. Serum alpha-fetoprotein for diagnosis of hepatocellular carcinoma in patients with chronic liver disease: Influence of HBsAg and anti-HCV status. J Hepatol 2001;34:570-5.

117. Villeneuve JP, Condreay LD, Willems B, et al. Lamivudine treatment for decompensated cirrhosis resulting from chronic hepatitis B. Hepatology 2000;31:207-10

18. Sponseller CA, Bacon BR, Di Bisceglie AM. Clinical improvement in patients with decompensated liver disease caused by hepatitis B after treatment with lamivudine. Liver Transpl 2000;6:715-20.

119. Kuwahara R, Kumashiro R, Inoue H, et al. Adefovir dipivoxil as a treatment for hepatic failure caused by lamivudine-resistant HBV strains. Dig Dis Sci 2004:49:300-3.

120. Homann C, Krogsgaard K, Pedersen C, Andersson P, Nielsen JO. High incidence of hepatitis B infection and evolution of chronic hepatitis B infection in patients with advanced HIV infection. J Acquir Immune Defic Syndr 1991;4:416-20.

121. Thio CL, Seaberg EC, Skolasky R Jr, et al; Multicenter AIDS Cohort Study. HIV-1, hepatitis B virus, and risk of liver-related mortality in the Multicenter Cohort Study (MACS). Lancet 2002;360:1921-6.

122. Gilson RJ, Hawkins AE, Beecham MR, et al. Interactions between HIV and hepatitis $\mathrm{B}$ virus in homosexual men: Effects on the natural history of infection. AIDS 1997;11:597-606.

123. Wong EK, Bodsworth NJ, Slade MA, Mulhall BP, Donovan B. Response to hepatitis B vaccination in a primary care setting: Influence of HIV infection, CD4+ lymphocyte count and vaccination schedule. Int J STD AIDS 1996; 7:490-4.

124. Benhamou Y, Bochet M, Thibault V, et al. Safety and efficacy of adefovir dipivoxil in patients co-infected with HIV-1 and lamivudine-resistant hepatitis B virus: An open-label pilot study. Lancet 2001;358:718-23.

125. Benhamou Y, Thibault V, Vig P, et al. Safety and efficacy of adefovir dipivoxil in patients infected with lamivudine-resistant hepatitis B and HIV-1. J Hepatol 2006;44:62-7.

126. Pessoa W, Gazzard B, Huang A, et al. Entecavir in HIV/HBV co-infected patients (safety and efficacy in a phase II study [ETV-038]). Abstract 123. XIIth Conference on Retroviruses and Opportunistic Infections. Boston, February 22 to 25,2005

127. Benhamou Y, Bochet M, Thibault V, et al. Long-term incidence of hepatitis virus resistance to lamivudine in human immunodeficiency virus-infected patients. Hepatology 1999;30:1302-6

128. Benhamou Y, Fleury H, Trimoulet P, et al; TECOVIR Study Group. Antihepatitis B virus efficacy of tenofovir disoproxil fumarate in HIV-infected patients. Hepatology 2006;43:548-55

129. Raimondo G, Brunetto MR, Pontisso P, et al; Associazione Italiana Studio Fegato Cooperative Group. Longitudinal evaluation reveals a complex spectrum of virological profiles in hepatitis B virus/hepatitis $C$ virus coinfected patients. Hepatology 2006;43:100-7.

130. Liu CJ, Chen PJ, Lai MY, Kao JH, Jeng YM, Chen DS. Ribavirin and interferon is effective for hepatitis $\mathrm{C}$ virus clearance in hepatitis B and C dually infected patients. Hepatology 2003;37:568-76.

131. Euler GL, Copeland JR, Rangel MC, Williams WW. Antibody response to postexposure prophylaxis in infants born to hepatitis B surface antigenpositive women. Pediatr Infect Dis J 2003;22:123-9.

132. van Zonneveld M, van Nunen AB, Niesters HG, de Man RA, Schalm SW, Janssen HL. Lamivudine treatment during pregnancy to prevent perinatal transmission of hepatitis B virus infection. J Viral Hepat 2003;10:294-7.

133. Xu WM, Cui YT, Wang L, et al. Efficacy and safety of lamivudine in late pregnancy for the prevention of mother-child transmission of hepatitis B (a multicenter, randomised, double-blind, placebo-controlled study). Hepatology 2004:40:273A. 
134. Watts DH, Covington DL, Beckerman K, et al. Assessing the risk of birth defects associated with antiretroviral exposure during pregnancy. Am J Obstet Gynecol 2004;191:985-92.

135. Han SH. Extrahepatic manifestations of chronic hepatitis B. Clin Liver Dis 2004;8:403-18.

136. Lin CY. Treatment of hepatitis B virus-associated membranous nephropathy with recombinant alpha-interferon. Kidney Int 1995;47:225-30.

137. Gan SI, Devlin SM, Scott-Douglas NW, Burak KW. Lamivudine for the treatment of membranous glomerulopathy secondary to chronic Hepatitis B infection. Can J Gastroenterol 2005;19:625-9.

138. Simpson ND, Simpson PW, Ahmed AM, et al. Prophylaxis against chemotherapy-induced reactivation of hepatitis B virus infection with lamivudine. J Clin Gastroenterol 2003;37:68-71.

139. Lau GK, He ML, Fong DY, et al. Preemptive use of lamivudine reduces hepatitis B exacerbation after allogeneic hematopoietic cell transplantation. Hepatology 2002;36:702-9.

140. Kohrt HE, Ouyang DL, Keeffe EB. Systematic review: Lamivudine prophylaxis for chemotherapy-induced reactivation of chronic hepatitis B virus infection. Aliment Pharmacol Ther 2006;24:1003-16.

141. Gish RG, McCashland T. Hepatitis B in liver transplant recipients. Liver Transpl 2006;12(11 Suppl 2):S54-64.

142. Viral hepatitis guidelines in hemodialysis and transplantation. Am J Transplant 2004;4(Suppl 10):72-82.

143. Chung RT, Feng S, Delmonico FL. Approach to the management of allograft recipients following the detection of hepatitis $\mathrm{B}$ virus in the prospective organ donor. Am J Transplant 2001;1:185-91.

144. McMahon BJ, Holck P, Bulkow L, Snowball M. Serologic and clinical outcomes of 1563 Alaska natives chronically infected with hepatitis B virus. Ann Intern Med 2001;135:759-68.

145. Bortolotti F, Cadrobbi P, Crivellaro C, et al. Longterm outcome of chronic type $\mathrm{B}$ hepatitis in patients who acquire hepatitis $\mathrm{B}$ virus infection in childhood. Gastroenterology 1990;99:805-10.

146. Lok AS, Lai CL. A longitudinal follow-up of asymptomatic hepatitis B surface antigen-positive Chinese children. Hepatology 1988;8:1130-3.

147. Evans AA, Fine M, London WT. Spontaneous seroconversion in hepatitis B e antigen-positive chronic hepatitis B: Implications for interferon therapy. J Infect Dis 1997;176:845-50.
148. Marx G, Martin SR, Chicoine JF, Alvarez F. Longterm follow-up of chronic hepatitis B virus infection in children of different ethnic origin. J Infect Dis 2002;186:295-301.

149. Bortolotti F. Treatment of chronic hepatitis B in children. J Hepatol 2003;39(Suppl 1):S200-5.

150. Vo Thi Diem H, Bourgois A, Bontems P, et al. Chronic hepatitis B infection: Long term comparison of children receiving interferon alpha and untreated controls. J Pediatr Gastroenterol Nutr 2005;40:141-5.

151. Bortolotti F, Jara P, Barbera C, et al. Long term effect of alpha interferon in children with chronic hepatitis B. Gut 2000;46:715-8.

152. Sokal EM, Conjeevaram HS, Roberts EA, et al. Interferon alfa therapy for chronic hepatitis B in children: A multinational randomized controlled trial. Gastroenterology 1998;114:988-95.

153. Jonas MM, Kelley DA, Mizerski J, et al. Clinical trial of lamivudine in children with chronic hepatitis B. N Engl J Med 2002;346:1706-13.

154. Sokal EM, Kelly DA, Mizerski J, et al. Long-term lamivudine therapy for children with HBeAg-positive chronic hepatitis B. Hepatology 2006:43:225-32.

155. Gunson RN, Shouval D, Roggendorf M, et al; European Consensus Group. Hepatitis B virus (HBV) and hepatitis C virus (HCV) infections in health care workers (HCWs): Guidelines for prevention of transmission of $\mathrm{HBV}$ and HCV from HCW to patients. J Clin Virol 2003;27:213-30.

156. Farci P, Roskams T, Chessa L, et al. Long-term benefit of interferon alpha therapy of chronic hepatitis D: Regression of advanced hepatic fibrosis. Gastroenterology 2004;126:1740-9.

157. Castelnau C, Le Gal F, Ripault MP, et al. Efficacy of peginterferon alpha-2b in chronic hepatitis delta: Relevance of quantitative RT-PCR for follow-up. Hepatology 2006;44:728-35.

158. Niro GA, Ciancio A, Gaeta GB, et al. Pegylated interferon alpha-2b as monotherapy or in combination with ribavirin in chronic hepatitis delta. Hepatology 2006;44:713-20.

159. American Gastroenterological Association Medical Position Statement: Guidelines for the use of enteral nutrition. Gastroenterology 1995;108:1280-1.

160. Hadziyannis SJ, Tassopoulos NC, Heathcote EJ, et al; Adefovir Dipivoxil 438 Study Group. Adefovir dipivoxil for the treatment of hepatitis B e antigen-negative chronic hepatitis B. N Engl J Med 2003;348:800-7.

161. Bzowej N, Chan H, Lai CL, et al. A randomized trial of telbivudine (LDT) vs. adefovir for HBeAg-positive chronic hepatitis B: Final week 52 results. Hepatology 2006;44(Suppl 1):563A. 


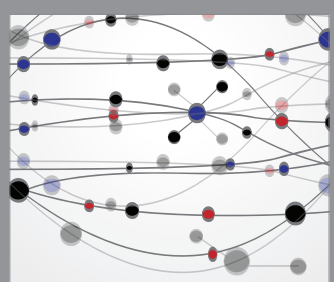

The Scientific World Journal
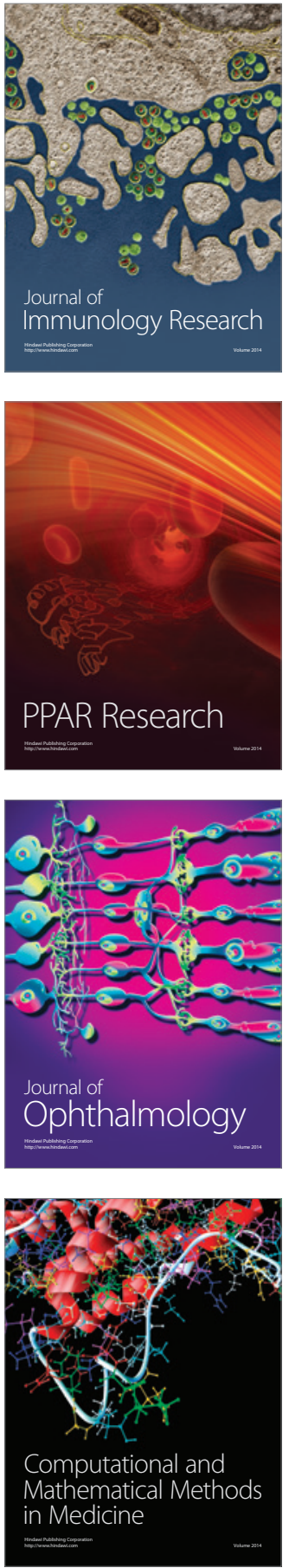

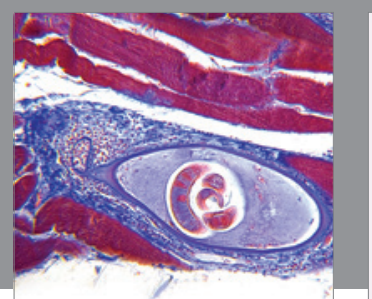

Gastroenterology Research and Practice

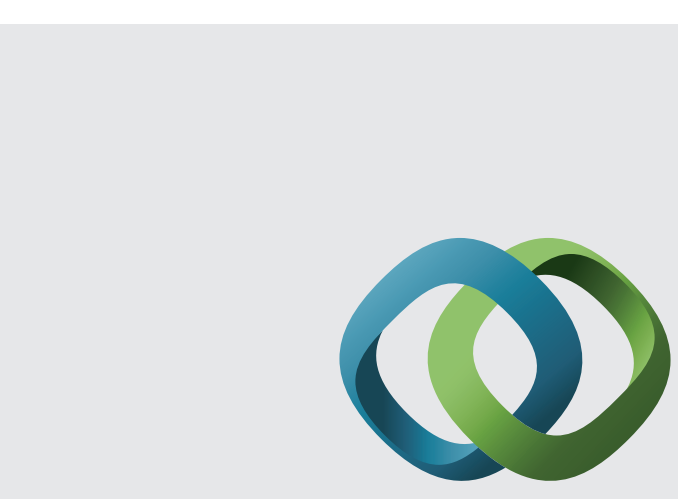

\section{Hindawi}

Submit your manuscripts at

http://www.hindawi.com
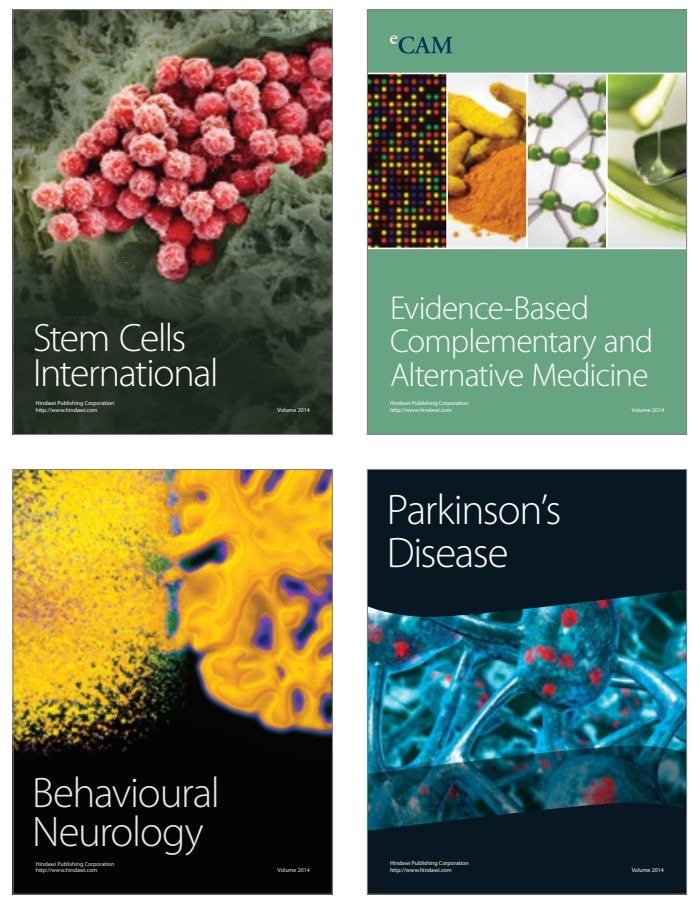
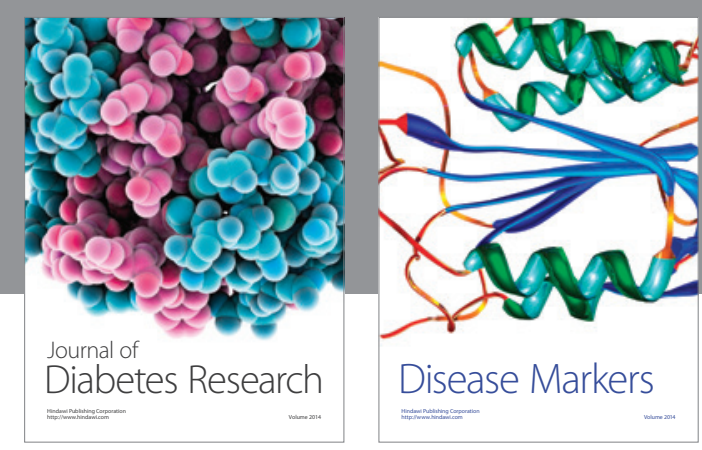

Disease Markers
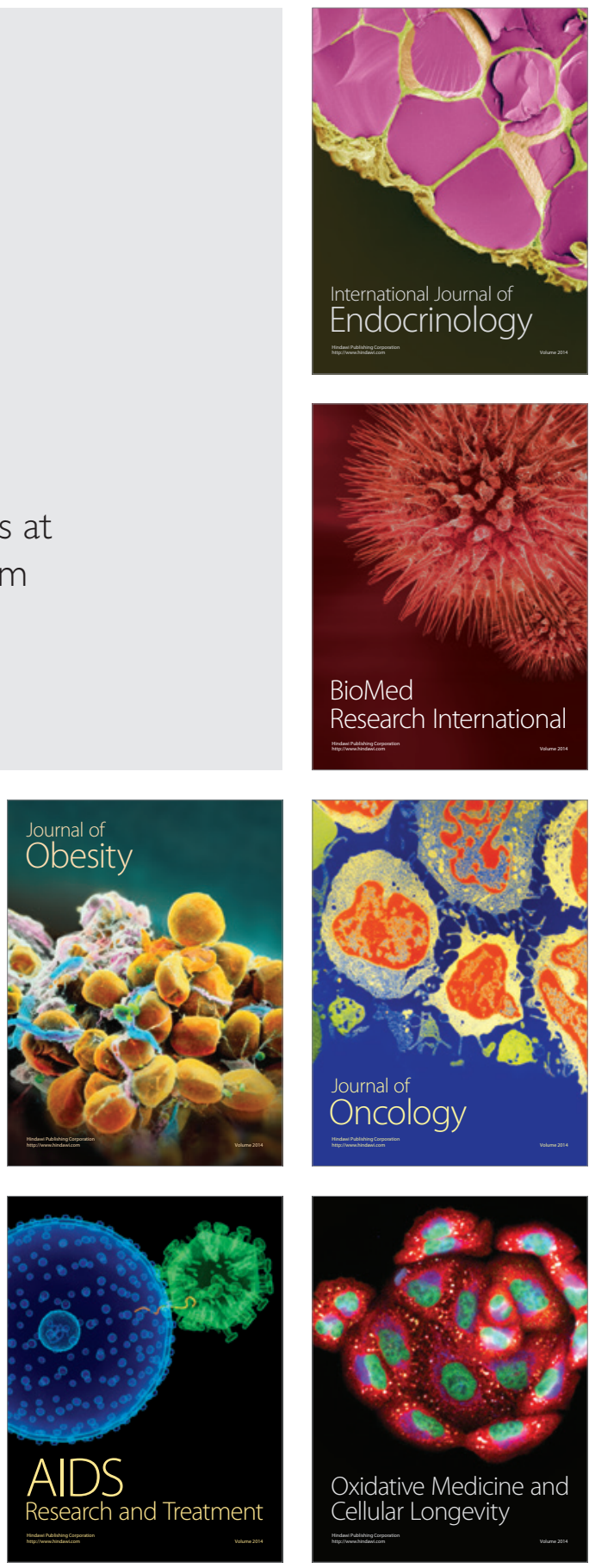